Int. J. Dev. Biol. 48: 1031-1044 (2004)

doi: $10.1387 / \mathrm{ijdb} .041854 \mathrm{jg}$

\title{
Congenital hereditary cataracts
}

\author{
JOCHEN GRAW* \\ GSF-National Research Center for Environment and Health, Institute of Developmental Genetics, Neuherberg, Germany
}

\begin{abstract}
Congenital cataracts are rare and occur in developed countries with a frequency of 30 cases among 100,000 births with a further 10 cases being diagnosed during childhood. They reflect mainly genetically caused developmental alterations in the lens and surrounding ocular tissues. Even if modern Human Genetics has made large steps forward in the characterization of human hereditary disorders, the underlying developmental processes can only be investigated in model organisms. The mouse is such a good model because of its similarity (as a mammal) and its genetic characterization. This review brings together our genetic and developmental knowledge of congenital, human cataracts with the corresponding mouse models. First, early events will be influenced by genes coding for transcription factors like Pax6, Pitx3, Maf or Sox. If the lens is maturing, mutations affecting the lens membranes (aquaporins/Mip, Lim-2 or connexins) or the structural proteins of the cytosol of the lens fiber cells (the crystallins) become more important. From a genetic point of view it becomes obvious that cataract-causing mutations are not distributed randomly. The discovery of a broad variety of genes important for eye and lens development made much progress in the recent years. Nevertheless, there still remains a long list of mutations to be characterized and functionally investigated both in mouse and man indicating a broad genetic heterogeneity in that which clinicians simply refer to as a "cataract".
\end{abstract}

KEY WORDS: lens, development, cataract, genetics

\section{Introduction}

Cataracts as lens opacities are a group of well-known diseases since centuries; particularly in the elderly population the frequency is quite common. There are a lot of ongoing epidemiological studies to figure out risk factors; however, there are only a few factors recognized like UV-B exposure, low antioxidant intake, certain medications, cigarette smoking, diabetes and gout as well as family history (McCarty, 2003).

In contrast to these age-related forms of cataract, congenital cataracts or cataracts in early childhood are rather rare and occur in developed countries with a frequency of 30 cases among 100.000 births; with a further 10 cases being diagnosed by the age of 15 years (mainly as dominant forms). Rates are likely to be higher in developing countries because of rubella infections and consanguinity (for the recessive forms; Foster et al., 1997).

To learn more about developmental processes and their disease-causing disturbances, it is helpful to look for appropriate animal models. Such a model is the mouse: a mammal like human, but much smaller, with a shorter generation time and extremely well characterized from a genetic point of view. The first evaluation of large mouse populations for mutations affecting the eye lens at birth was initiated in 1979, when Kratochvilova and Ehling described for the first time the systematic screening for murine dominant cataract mutants in the $F_{1}$ generation after paternal radiation treatment. The systematic screening for eye mutants was extended to the use of ethylnitrosourea (ENU) as mutagenic agent (Ehling et al., 1985; West and Fisher 1986). Some of the mutants were grouped into allelic series (Kratochvilova and Favor, 1992; Everett et al., 1994; Favor 1995). All the mutant phenotypes characterized up to now are caused by single dominant gene mutations. Together with further mutants described in the literature, a mosaic can be built up reflecting important steps during lens development and differentiation. In this review mouse mutants suffering from hereditary, congenital (or early childhood cataract) will be discussed and compared to corresponding human disorders; however, transgenic models leading to cataract will not be included, because they are in the focus of the article by Paul Overbeek (this issue). An overview of mouse eye development is given in Fig. 1.

Abbreviations used in this paper: MARE, Maf responsive element.

\footnotetext{
*Address correspondence to: Dr. Jochen Graw. GSF-National Research Center for Environment and Health, Institute of Developmental Genetics, Laboratory of Molecular Eye Development, Ingolstädter Landstr. 1, D-85764 Neuherberg, Germany.

Fax: +49-89-3187-4620. e-mail: graw@gsf.de Web: http://www.gsf.de/idg/groups/molecular_eye/start.html
} 


\section{Mutations at early stages of lens development}

\section{Pax6 and Pitx3}

One of the central genes in eye development is the paired-box gene Pax6, which was recognized as being affected in the mouse and rat Small eye (Sey) mutants (Hill et al., 1991; Matsuo et al., 1993). Pax6maps at mouse chromosome 2; the actual list of the Jackson Laboratory (http://www.informatics.jax.org/searches; April 2004) contains 25 alleles in the mouse, 4 of them are targeted mutations. In the "classical" Sey mutant, the failure in lens development is attributed to a defect in the inductive interaction between the optic vesicle and the overlying ectoderm, since these tissues fail to make discrete contacts (Hogan et al., 1986). During embryogenesis, the heterozygotes express obvious microphthalmia with a triangular-shaped pupil, and homozygotes express anophthalmia with severe craniofacial defects (Hogan et al., 1988). Homozygotes die around birth because of breathing problems.

Usually, the expressivity of heterozygous Pax6-mutations is variable with mutant carriers expressing a range of phenotypes from small anterior polar cataracts to the more extreme phenotype of anterior polar opacity, corneal adhesions, iris abnormalities and microphthalmia. Furthermore, the degree of phenotype expressed between the eyes of an individual mutation carrier was variable (Favor et al., 2001).

In humans, PAX6 mutations lead mainly to aniridia, cataracts and Peter's anomaly (Glaser et al., 1994; Hanson and van Heyningen, 1995; Prosser and van Heyningen, 1998; Hanson et al., 1999; van Heyningen and Williamson, 2002; Morrison et al., 2002). Although further studies are needed to establish clear genotype-phenotype correlations, most mutations found to date affects exons 5 and 6 and their connecting intron region; a few mutations have also been found in the homeodomain. Genotype and phenotype information for human PAXG mutations is collected in a database, which contains more than 300 records (http:/ /pax6.hgu.mrc.ac.uk/).
The morphological alterations correspond to the expression pattern of Pax6. Pax6transcripts are first detected in the presumptive fore- and hindbrain of 8-day-old mouse embryos; at E8.5 it is present in the optic sulcus, the lateral evagination at the basis of the forebrain. Later, at E9.5, Pax6is expressed in the optic vesicle, the optic stalk, and the surface ectoderm, which will give rise to the lens. Between E10 and E12, Pax6is observed in the inner layer of the optic cup, in the lens and in the surface ectoderm, which gives at this stage rise to the future cornea. In the elongating primary fiber cells, Pax6 has a posterior localization. At E15.5, Pax6 is expressed in the two layers of the neural retina, the anterior epithelium of the cornea, and in the lens. Beside the eye, Pax6 occurs in specific regions of the brain, the olfactory epithelium, and the pancreas (Walther and Gruss, 1991; Hanson and van Heyningen, 1995; St.Onge et al., 1997).

The second interesting gene in the context of early lens development is Pitx3. In the mouse mutant aphakia (ak, Varnum and Stevens, 1968), the promotor of the Pitx3gene is affected by two deletions (Semina et al., 2000; Rieger etal., 2001). The phenotype is characterized at early stages of development by a small lens vesicle with a stable contact to the cornea ("lens stalk"). In later stages, the lens vesicle is degraded which leads to the formation of a lens-less eye giving this mutant its name. Another mutant line, Cat4 $^{a}$, shares one aspect with the aphakia mutant, the inhibition of the separation of the lens vesicle from the surface ectoderm (Grimes et al., 1998). However, Cat4a is mapped on mouse chromosome 8 (Favor et al., 1997) suggesting to be different from Pitx3.

In contrast to the mouse situation, mutations in the human PITX3gene are causative for congenital cataracts; in one of the two cases reported the phenotype includes also anterior segment mesenchymal dysgenesis (Semina etal., 1998). The phenotype of the mouse mutant as well as the disorders of the patients correlate to the expression pattern of the affected gene Pitx3. It is strongly expressed in the developing lens vesicle starting at day 11 of embryonic mouse development, but later also throughout the lens,

TABLE 1

MUTANT ALLELES CODING FOR MEMBRANE PROTEINS INVOLVED IN CONGENITAL CATARACTS

\begin{tabular}{|c|c|c|c|c|c|}
\hline Name & Allele Symbol & Phenotype & Molecular lesion & Consequence for Protein & Reference \\
\hline \multirow[t]{4}{*}{ Mip } & Cat ${ }^{F r}$ & Progressive degeneration of lens fiber cells & E.Tn insertion $\rightarrow$ splicing defect & Fusion protein & Shiels \& Bassnett, 1996 \\
\hline & Cat ${ }^{L o p}$ & Progressive degeneration of lens fiber cells & G151C Ala51Pro & Transmembrane domain 2 & Shiels \& Bassnett, 1996 \\
\hline & $H f i$ & Hydropic lens fibers (+/-) Total lens opacity (-/-) & 76 bp deletion in intron 2 splicing defect & $\begin{array}{l}\text { Loss of exon } 2 \\
\text { Loss of transmembrane } \\
\text { domains } 4 \& 5\end{array}$ & Sidjanin et al., 2001 \\
\hline & Cat ${ }^{\text {Tohm }}$ & Small eyes with opaque lenses & $\Delta 137-148 \Delta$ LAFG46-49 & Transmembrane domain 2 & Okamura et al., 2003 \\
\hline MIP & & Polymorphic lamellar cataract & $\mathrm{C} \rightarrow \mathrm{G}$ Thr138Arg & Transmembrane domain 4 & Berry et al., 2000 \\
\hline MIP & & Polymorphic lamellar cataract & $\mathrm{A} \rightarrow \mathrm{G}$ Glu134Gly & Transmembrane domain 4 & Berry et al., 2000 \\
\hline Lim2 & To3 & Total opacity with a dense cataract & G44T Gly15Val & Transmembrane domain 1 & Steele et al., 1997 \\
\hline \multirow[t]{2}{*}{ Gja1 } & Gja1\%* & Intracellular vacuoles & Targeted deletion & Loss of function & Gao and Spray 1998 \\
\hline & GJA1 & Oculodentodigital syndrome & A50C Tyr17Ser & Cytoplasmatic $\mathrm{N}$-terminus & Paznekas et al., 2003\# \\
\hline Gja3 & Gja3\% & Nuclear cataract & Targeted deletion & Loss of function & Gong et al., 1997 \\
\hline GJA3 & & Zonular pulverulent cataract & C560T Pro187Leu & Transmembrane domain 2 & Rees et al., 2000 \\
\hline GJA3 & & Zonular pulverulent cataract & A188G Asn63Ser & $1^{\text {st }}$ extracellular loop & Mackay et al., 1999 \\
\hline GJA3 & & Zonular pulverulent cataract & 1137ins C frameshift & Hybrid protein from codon 380 & Mackay et al., 1999 \\
\hline \multirow[t]{3}{*}{ Gja8 } & No2 & Nuclear and zonular cataract & $A \rightarrow C$ Asp $\rightarrow$ Ala & $1^{\text {st }}$ extracellular loop & Steele et al., 1998 \\
\hline & Aey5 & Nuclear and zonular cataract & T191C Val64Ala & $1^{\text {st }}$ extracellular loop & Graw et al., 2001b \\
\hline & $\mathrm{Gja}^{-}$ & microphthalmia and nuclear cataract & Targeted deletion & Loss of function & White et al., 1998 \\
\hline GJAB & & Zonular pulverulent cataract & C262T Pro88Ser & Transmembrane domain 2 & Shiels et al., 1998 \\
\hline GJAB & & Zonular nuclear pulverulent cataract & $\mathrm{G} \rightarrow \mathrm{A}$ Glu48Lys & $1^{\text {st }}$ extracellular loop & Berry 1999 \\
\hline
\end{tabular}

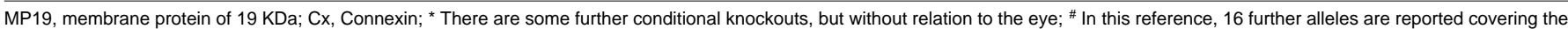
entire GJA1 gene and resulting in the same phenotype. 
Fig.1. Histological sections through a developing mouse eye. At E 9.5, the lens placode invaginates forming the lens pit $(L P)$; the underlying neuroectoderm follows this inward movement forming the inner layer (IL) of the optic cup. It will further develop into the neural part of the retina; the outer layer (OL) gives rise to the future pigment layer (or pigment epithelium) of the retina. When the lens vesicle $(L V)$ is formed and detached from the surface ectoderm, the primary lens fibres (PLF) begin to elongate from the posterior part (E11.5). The two layers $(O L, I L)$ of the retina are closely attached, and the optic stalk (OS) maintains the connection to the diencephalon. When the lens vesicle is filled by the primary lens fibres, the epithelial cells divide and move to the lens equator. At the lens bow (LB) region, they elongate as they differentiate into secondary lens fibre cells. This process continues throughout life and leads to superficial layers of secondary fibre cells. The cell nuclei at E15.5 are arranged in a wave-like manner through the lens. At that time, the cornea $(C)$ is also present. The nerve fibres (NFL, nerve fibre layer of the optic cup) join to the optic nerve $(O N)$, which is growing retrograde to the brain through the optic stalk. One week after birth (P7), the eye is finally developed and the centre of the lens is free of cellular organells like nucleior mitochondria ( $C$, cornea; $L$, lens, $L E$, lens epithelium; LB, lens bow; $R$, retina). (Previously published by Graw and Löster, 2003).

particularly in the anterior epithelium and equator region (Semina et al., 1997). Moreover, there are recent reports that Pitx 3 is also expressed in the dopaminergic neurons of the substatia nigrain the brain (Nunes etal., 2003); therefore, it is not surprising that aphakia mice suffer also from a selective loss of these particular neurons (Hwang et al., 2003) and a malformation of the mesencephalic dopamine system (Smidt et al., 2004).

\section{Maf, Sox, Fox and Eya}

There are some other genes coding for transcription factors important for eye and lens development, Maf, Sox1, Sox2, FoxC1 and FoxE3. Particularly, Maf and Sox1 act as transcription factors on the promoters of the $\gamma$-crystallin encoding genes (Cryg).

The Fox-transcription factors are characterized by an 110amino-acid motif originally defined as a DNA-binding domain in the Drosophila transcription factor forkhead (Fox: forkhead box). Recently, Blixt et al., (2000) characterized a mutation in FoxE3 to be causative for the phenotype in an old mouse mutant, dysgenic lens $(d y)$. In this mutant, the lens vesicle fails to separate from the ectoderm causing the lens and the cornea to fuse. In human, mutations in FOXE3 lead to anterior segment ocular dysgenesis (Semina et al., 2001). Similarly, mutations in the human FOXC1 and corresponding mouse mutant lead to a similar phenotype with additional glaucoma (Nishimura et al., 2001; Hong et al., 1999).

The Maf family of basic region leucine zipper (bZIP) transcription factors was first identified through the $v$-maf oncogene, an avian retrovirus transforming gene (Nishizawa, et al., 1989). In chicken and Xenopus, it was demonstrated by several authors that $\mathrm{L}-M A F$ is involved in the regulation of crystallin expression. L-Maf is first expressed at the lens placode and is maintained specifically in lens cells (Shimada et al., 2003). The mouse homologue to the Xenopus L-Mafis obviously $\mathrm{Nr} /$ coding for a neural retina-specific leucine zipper protein; whereas the mouse homologue to the chicken L-Maf is Maf-B (NCBI UniGene). The third mammalian member of the Maf family demonstrating important properties concerning lens development is c-Maf. The targeted deletion of cMaf in the mouse leads to a stop of lens primery fiber cell elongation at the lens vesicle stage (Ring et al., 2000); the same feature was

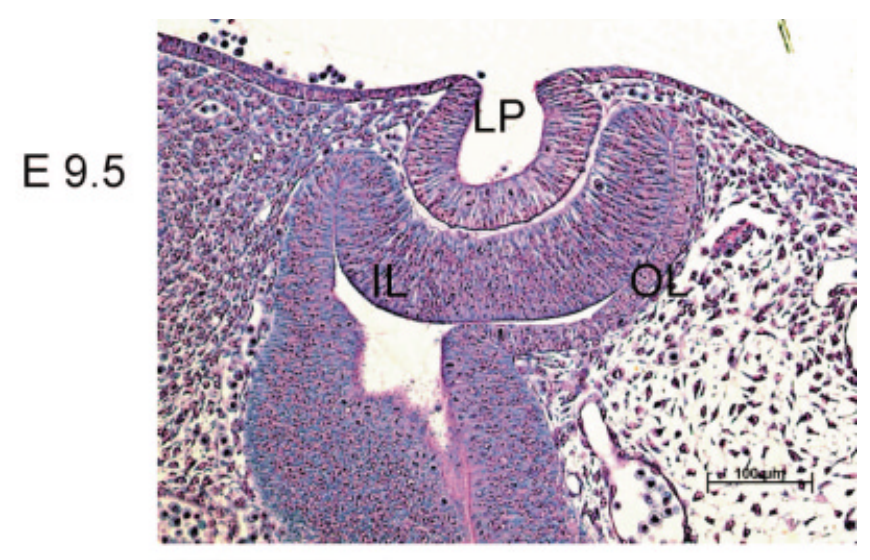

E11.5

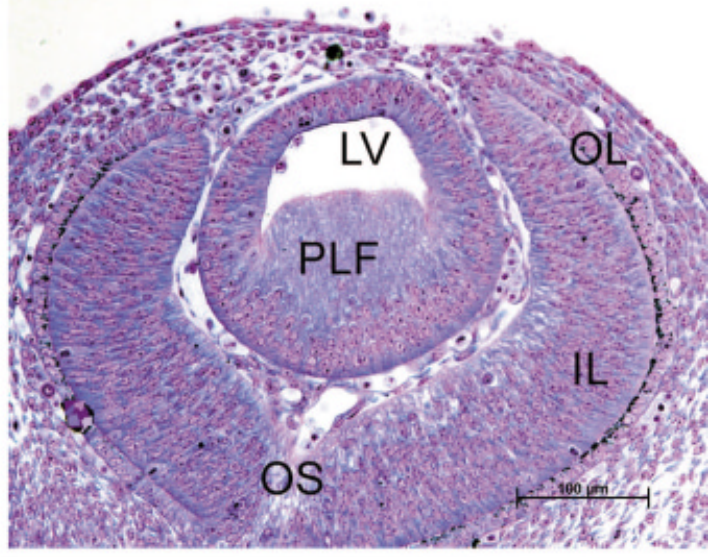

E15.5
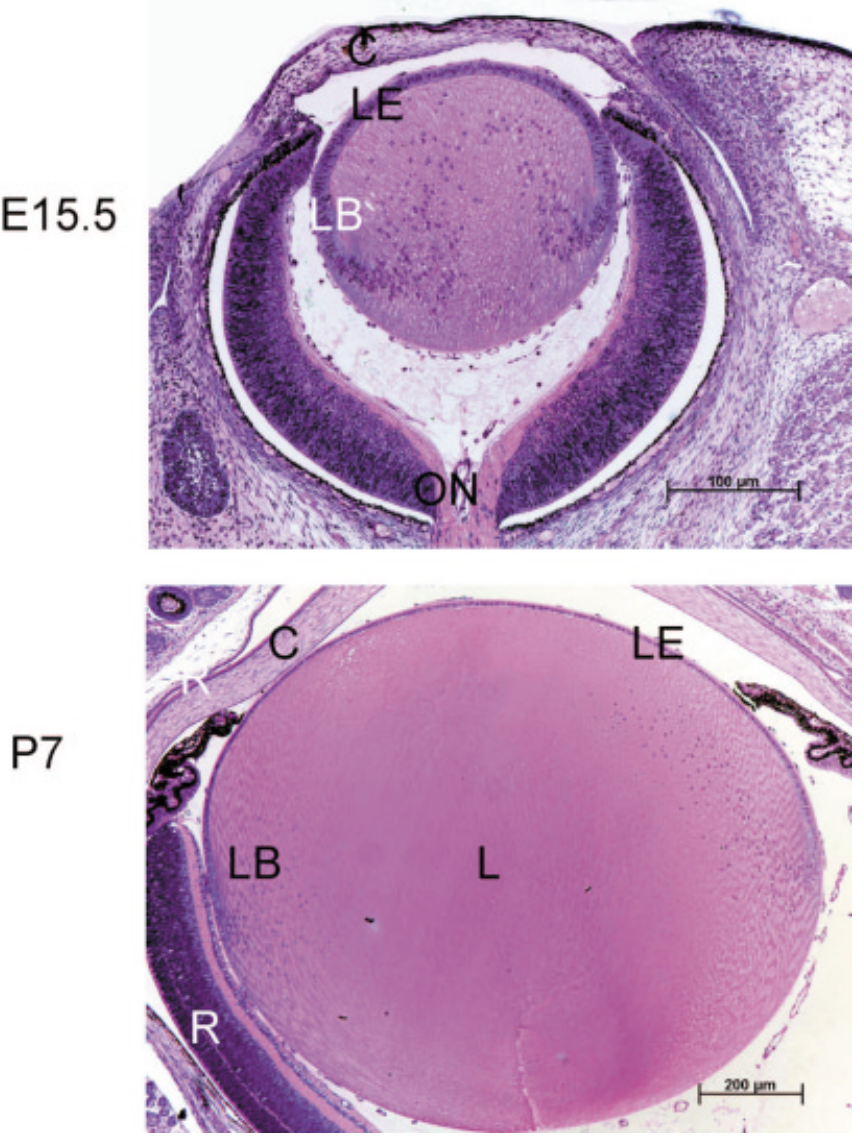
published recently for a mild pulverulent cataract mutant in mouse (opaque flecks in the lens, Opj; Lyon et al., 2003). The point mutation affects the basic region of the DNA-binding domain.

In general, Maf binds as homo- or heterodimer to two known Maf responsive elements (MAREs), with varying affinities and transactivation potentials (Kataoka et al., 1993; 1996). MAREs are found in the promoters of the crystallin-encoding genes and Pitx 3 (Semina et al., 2000; Ogino et al., 1998). Recently, two families were identified suffering from ocular developmental abnormalities (in one case, cataract is associated with anterior segment dysgenesis and microphthalmia; in the other case, cataract is associated with microcornea and iris coloboma). In the first family, congenital cataract co-segregated with a translocation; its breakpoint on $16 q 23$ lies close to the lens-development gene, $M A F$, and transects the common fragile site $F R A 16 D$ (Jamieson et al., 2002). In the second family, a causative mutation for congenital cataract (observed over three generations) was identified affecting the DNAbinding domain of MAF (Jamieson et al., 2002). These findings implicate $M A F$ as a disease gene in the complex pathway of transcriptional regulatory genes involved in lens and anterior segment development.

The Sox-family of transcription factors has a HMG domain (high mobility group) in common; the founder of this family is the Srygene (sex-determining region of $Y$ chromosome; Koopman, 1999). The genes Sox1, Sox2and Sox3belong to subgroup B (Kamachi et al., $2000)$; they are expressed in the mouse in the central nervous system and in the sensory placodes. Particularly, Sox2 is expressed during early eye development in the lens placode in the portion of the ectoderm that is in contact with the optic cup and invaginates to form the lens vesicle. This invagination coincides with the onset of Sox1 expression in the mouse lens placode. At later stages, Sox2is downregulated and Sox1 comes up (Kamachi et al., 1998).

A targeted deletion of Sox1 in mice caused microphthalmia and cataract. Mutant lens fiber cells fail to elongate, probably as a result of an almost complete absence of Cryg transcripts (Nishiguchi et al., 1998). The phenotype of the homozygous Sox1 deletion mutant is very similar to the most severe Crygmutation, Cryge ${ }^{t}$. In contrast to Sox1, mutations in the human SOX2 gene cause anophthalmia (without cataract; Fantes et al., 2003), however, the heterozygous knockout mice of Sox2 appeared normal, but the homozygous mutants are peri-implantationally lethal (Avilion etal., 2003).

Another mammalian family of genes has close relationship to a Drosophila gene: eyes absent. In mouse and man four members belong to this family (Eya1-4), but so far only a mutation in the human EYA1 gene is reported to lead to cataract (together with Peter's anomaly and nystagmus; Azuma et al., 2000).

\section{Miscellaneous}

In addition, there are several other genes (e. g. Shh, rx/eyeless, Lhx, Bmp4or Bmp7) known to be expressed at these early stages; however, the phenotypes of the corresponding knock-out or nullmutants are causing mainly anophthalmia (the loss of the entire ocular structure) or microphthalmia (small eye), but no cataracts. For further discussion of these genes refer to previous reviews and references therein (e.g. Graw, 2003).

After the lens placode stage, the next important step is the formation of the lens vesicle. Its key role is addressed by some mouse mutants like extra toes (Gli3 ${ }^{X t}$;Franz and Besecke, 1991), eye lens aplasia (elap, Aso et al., 1995, 1998), head blebs (heb, Varnum and Fox, 1981) or myelencephalic blebs ( $m y$; Center and Polizotto, 1992). All these mouse models have in common a microphthalmic phenotype with major disturbances on most of the ocular tissues. The lens is frequently missing; correspondingly, these mutations are not associated with cataracts. One of them is molecularly characterized (extra toes, Gli3; Hui and Joyner, 1993).

\section{Mutations affecting lens membranes}

As demonstrated above, only in a few cases cataracts are formed at the early stages of eye development. However, one might assume that more and diverse phenotypes of cataracts occur, if stages are affected, when the lens vesicle is already formed. In this chapter those mutants are described affecting the membrane of lens cells (an overview is given in Tab. 1).

\section{Aquaporin/MIP}

One of the first detected cataract mutations is the Cataract Fraser(CatFr; Fraser and Schabtach, 1962). In this mutant, the cell nuclei in the deep cortex become abnormally pycnotic (beginning at E14), degeneration of cytoplasm and destruction of the lenticular nucleus follow (Zwaan and Williams, 1969). Cat $^{F r}$ was shown to be allelic with another mouse mutant, referred to as Lens opacity (Lop). The two alleles, Cat ${ }^{L o p}$ and $C a t^{F r}$, were mapped $20 \mathrm{cM}$ distal to Steel (S) at chromosome 10 (Lyon et al., 1981; MuggletonHarris et al., 1987). A candidate gene for the Catlocus encodes the membrane intrinsic protein (gene symbol: Mip; Griffin and Shiels, 1992). Sequence analysis revealed that the $\mathrm{Cat}^{\mathrm{Fr}}$ mutation is due to a transposon-induced splicing error leading to a truncated form of Miptranscripts. However, the mutation in the Cat ${ }^{L o p}$ leads to a single amino-acid substitution, which inhibits targeting of Mip to the cell membrane (Shiels and Griffin, 1993; Shiels and Bassnett, 1996). Recently, a new mutant allele (Cat ${ }^{\text {Tohm }}$ ) was reported, which is characterized by a 12 bp deletion and a corresponding loss of 4 amino acids within the second transmembrane region (Okamura et al., 2003). Mip forms specialized junctions between the fiber cells and can be first detected in the primary fiber cells of the early lens vesicle. In situ hybridization demonstrated that Mip expression is highest in the elongating fiber cells in the bow region of the lens; Mip antiserum specifically decorates fiber cell membranes, highlighting their regular anterior to posterior organization (Shiels and Griffin, 1993; Zhou et al., 2002). Mip is also referred to aquaporin; a recent review was published by Agre and Kozono (2003)

\section{LIM}

The total opacity To3 is placed on chromosome 7 (Kerscher et al., 1996). Mice heterozygous or homozygous for the To3mutation exhibit a total opacity of the lens with a dense cataract. Additionally, homozygotes exhibit microphthalmia and abnormally small eyes. Histological analysis revealed vacuolization of the lens and gross disorganization of the fibers; posterior lens rupture can be observed only in homozygotes. The To3mutation was characterized as a single $\mathrm{G} \rightarrow \mathrm{T}$ transversion within the first exon of the Lim2gene coding for a lens-specific integral membrane protein, MP19. It was predicted that this DNA change results in a nonconservative substitution of a valin for the normally encoded glycine at amino acid \#15 of the MP19 protein (Steele et al., 1997). Lim2mRNA can 
be found in the head region of mouse embryos from embryonic day 12 on (Zhou et al., 2002). In human, a missense mutation in the $\angle I M 2$ gene is associated with autosomal recessive presenile cataract (Pras et al., 2002).

\section{Connexins in the lens}

The Gja8 gene encodes the lens-specific gap junction membrane channel protein $\alpha 8$, which is also referred to as connexin 50 or MP70. It maps to mouse chromosome 3 (Kerscher et al., 1995) and was demonstrated recently to be affected by a single $A \rightarrow C$ transversion within codon 47 of the No2(nuclear opacity 2) mouse cataract. The sequence alteration is predicted to result in the nonconservative substitution of Ala for the normally encoded Asp (Steele et al., 1998). A similar phenotype (microphthalmia and nuclear cataract) was observed in $C \times 50$ null mice (White et al., 1998). A mutation in the corresponding human gene leads to a zonular pulverulent cataract (Shiels et al., 1998) or nuclear cataract (Willoughby et al., 2003). The Cx50-encoding gene Gja8 is expressed mainly in lens fiber cells. However, Dahm et al., (1999) showed that $\mathrm{Cx} 50$ (which is identical to the lens membrane protein MP70; White et al., 1992) can also be found in the epithelial cells forming complexes with $\mathrm{Cx43}$ (see below).

A knockout mutation of another type of connexin, the gene coding for connexin46 (or gap junction protein $\alpha 3$; gene symbol Gja3), exhibits nuclear cataract, which was associated with the proteolysis of crystallins. Obviously, there is no influence on the early stages of lens formation (Gong et al., 1997). Gja3is mapped to mouse chromosome 14 (Haeflinger et al., 1992). Recently, a novel mutation in human $G J A 3$ gene $(T T C \rightarrow$ TTA) results in a $\mathrm{Phe} \rightarrow$ Leu substitution in the first transmembrane region of human connexin46. The mutation was proven to be causative for a congenital nuclear pulverulent cataract (Jiang et al., 2003); however, a few years ago, Rees et al., (2000) and Mackay etal., (1999) showed also mutations in the human GJA3gene leading to zonular pulverulent cataracts. The two mutations affect different parts of the protein (the extra- and intracellular domain, resp.)

Similarly, disruption of the gene coding for connexin43 (gene symbol: Gja1 for gap junction membrane channel protein $\alpha 1$ ) demonstrated normal development of the lens and differentiation of the fiber cells at the bow region. The lenses of the Gja 1\% mice exhibit grossly dilated extracellular spaces and intracellular vacuoles. These changes suggest that the osmotic balance within these cells is markedly altered (Gao and Spray 1998). Gja 1 is mapped to mouse chromosome 10 (29 cM from the centromere; Hsieh et al., 1991). In agreement with the pleiotropic action of the gene, Gja1 is expressed in very early mouse embryogenesis beginning in the blastocyst stage; later on, its expression is associated with many developmental processes involving the eye and otic vesicle, branchial arches, and migratory cells of the neural crest and sklerotomes (Paznekas et al., 2003).

\section{Mutations affecting the structural proteins of the lens cytosol}

Up to $90 \%$ of the soluble protein in the postmitotic lens cells consists of proteins, which are referred to as $\alpha-, \beta$-, and $\gamma$-crystallins (Mörner, 1893). The $\alpha$-crystallins form high-molecular aggregates. Recent findings on the structure and function of $\alpha$-crystallins demonstrated that they have chaperone activity and belong to the family of the small heat shock proteins. In contrast to $\alpha \mathrm{B}$-crystallin (gene symbol: Cryab), which is ubiquitously expressed, the $\alpha \mathrm{A}$ crystallin (gene symbol: Cryaa) occurs mainly in the lens. The $\beta / \gamma$ crystallin superfamily exhibits a characteristic protein motif, the socalled Greek key motif, in a quadruple organization. It is considered to be essential for the extremely high protein concentration within the lens (for reviews on crystallins see Wistow \& Piatigorsky, 1988; Graw 1997; Bhat, 2003).

Moreover, because of the unique morphology of the lens fiber cells it is not surprising that also unique cytoskeletal proteins exist to be expressed more or less specifically in the lens. Among them, CP49 has to be mentioned, because its alteration leads to alterations of lens transparency. An overview and summary for all of these mutations is given in Table 2 .

\section{The $\alpha$-crystallins}

A few years ago, a knockout of the $\alpha \mathrm{A}$-crystallin-encoding gene Cryaa, was published; it leads to a recessive phenotype (Brady et al., 1997). Cryaa ${ }^{-1}$ lenses develop an opacification that starts in the nucleus and progresses to a general opacification with age. Cataract formation is finally caused by insolubility of the $\alpha \mathrm{B}$ crystallin. Cryaa is mapped to mouse chromosome 17; cataractcausing mutations are referred to as lop 18(recessive; Chang etal., 1999) and Aey7 (dominant; Graw et al., 2001a). In contrast, knockout mice of Cryab encoding $\alpha \mathrm{B}$-crystallin are cataract-free, but they die prematurely because of myopathy and some other organ defects (Brady et al., 2001). Cryab is mapped on mouse chromosome 9 (Xia et al., 1996).

In human, one of the most common familial forms of congenital cataracts is referred to as the autosomal dominant congenital cataract ( $A D C C$ ). An $A D C C$ locus was mapped recently to human chromosome 21q22.3 near the $\alpha \mathrm{A}$-crystallin encoding gene, CRYAA. By sequencing this candidate gene, Litt et al., (1998) found a missense mutation leading to an Arg $\rightarrow$ Cys exchange at the amino acid position 116, which is associated with $A D C C$ in this family. Another mutation (R49C) leads to a similar dominant phenotype (Mackay etal., 2003). In contrast to these two dominant phenotypes, Pras et al., (2000) demonstrated a nonsense mutation (W9X) in CRYAA to be causative for an autosomal recessive cataract in an inbred Jewish Persian family.

Additionally, in human two different cataract-causing mutations have been described in $C R Y A B$ : at first, Vicart et al., (1998) reported a dominant myopathy associated with cataract to be caused by a missense mutation (R120G). Subsequent in vitro studies demonstrated its defective chaperon-like function as the biochemical reason for formation of this particular type of cataract (Bova et al., 1999). Later on, Berry et al., (2001) reported another mutation in the human $C R Y A B$ gene causing dominant congenital cataract at the posterior pole of the lens. In a four-generation family of English descent, the authors mapped this type of cataract close to the $C R Y A B$ locus and found a deletion in exon 3 of $C R Y A B$ that resulted in a frameshift in codon 150 and an aberrant protein consisting of 184 residues. Because of these 35 new amino acids, this particular phenotype might be attributed to a dominant-negative function.

Since the $\alpha$-crystallins belong to the family of small heat-shock proteins, it might be interesting to note that a mutation in a gene coding for heat-shock transcription factor 4 (gene symbol HSF4) is associated with a dominant, lamellar cataract (Bu et al., 2002a) 


\section{The $\beta$-crystallins}

The first cataract mutantation which was characterized on a molecular level was the so-called Philly mouse. It was demonstrated to be caused by an in-frame deletion of $12 \mathrm{bp}$ in the $\beta$ B2crystallin encoding gene (Crybb2), resulting in a loss of four amino acids (Chambers and Russell, 1991). The region in which the deletion occurs is close to the carboxy-terminus and essential for the formation of the tertiary structure of the $\beta B 2$-crystallin. The increasing severity of the phenotype is temporally correlated to the expression of the Crybb2gene (Carper et al., 1982); Crybb2 is mapped to mouse chromosome 5 (Kerscher et al., 1995). After the 1 st postnatal week, the characteristic bow configuration of the nuclei in the lens cortex was replaced by a fan-shaped configuration, and swelling of the lens fibers occurred (Uga et al., 1980). Faint anterior opacities seen at postnatal day 15 are followed by sutural cataracts at day 25 , nuclear cataract at 30 days, lamellar perinuclear opacities at 35 days, and total nuclear with anterior and posterior polar cataracts at 45 days. Cataractogenesis is associated with an intralenticular increase in water, sodium, and calcium, and a decrease in potassium, reduced glutathione, and ATP. An altered membrane permeability is the cause of an increased outward leak (Kador et al., 1980). A similar phenotype (referred to as Aey2) was shown also to be caused by a mutation affecting the $4^{\text {th }}$ Greek Key motif in the $\beta B 2-c r y s t a l l i n$, however, in this case it was just an amino-acid exchange (Graw et al., 2001c).

Also for these mouse mutations homologous diseases have been described in man; the first of them was referred to as cerulean cataract (CCA2: congenital cataract of cerulean type 2). This particular cataract is characterized by peripheral bluish and white opacifications in concentric layers with occasional central lesions arranged radially. Litt et al., (1997) mapped this particular type of cataract to a region of human chromosome 22 containing three genes coding for different $\beta$-crystallins. Sequence analysis revealed that a chain-termination mutation in $C R Y B B 2$ is associated with this particular type of cataract in this family. Moreover, it turned out that the same mutation was found in three independent families suffering from different types of cataracts. Detailed analysis demonstrated that a sequence-specific gene conversion between $C R Y B B 2$ and its closely linked pseudogene is respon-

TABLE 2

\section{MUTANT ALLELES CODING FOR CRYSTALLINS OR CYTOSKELETAL PROTEINS INVOLVED IN CONGENITAL CATARACTS}

\begin{tabular}{|c|c|c|c|c|c|}
\hline Name & Allele Symbol & Phenotype & Molecular lesion & Consequence for Protein & Reference \\
\hline \multirow[t]{3}{*}{ Cryaa } & Cryaa & Recessive progressive opacity & Targeted deletion & Loss of function & Brady et al., 1997 \\
\hline & $10 p 18$ & Recessive nuclear and cortical cataract & $\mathrm{R} 54 \mathrm{H}$ & n.d. & Chang et al., 1999 \\
\hline & Aey7 & Nuclear cataract & V124E & n.d. & Graw et al., 2001a \\
\hline CRYAA & & Recessive cataract & w9x & Loss of function & Pras et al., 2000 \\
\hline CRYAA & & Dominant nuclear cataract & $\mathrm{R} 49 \mathrm{C}$ & Abnormal nuclear localization & Mackay et al., 2003 \\
\hline CRYAA & & Dominant nuclear cataract & $\mathrm{R} 116 \mathrm{C}$ & Increased membrane binding capacity & Cobb et al., 2000 \\
\hline Cryab & Cryaa & No ocular phenotype & Targeted deletion & Loss of function & Brady et al., 2001 \\
\hline \multirow[t]{2}{*}{$C R Y A B$} & & Myopathy with cataract & R120G & Irregular structure & Vicart et al., 1998; Bova et al., 1999 \\
\hline & & Posterior polar cataract & 450delA & Aberrant protein & Berry et al., 2001 \\
\hline Cryba1 & Po & Progressive cataract & Splicing intron $6 \mathrm{~W} 168 \mathrm{R} ; \Delta \mathrm{W} 168$ & 4th Greek Key motif & Graw et al., 1999 \\
\hline$C R Y B A 1$ & & Zonular cataract & Splicing intron 3 & n.d. & Kannabiran et al., 1998 \\
\hline$C R Y B A 1$ & & Pulverulent cataract & Splicing intron 3 & n.d. & Bateman et al., 2000 \\
\hline$C R Y B A 1$ & & Lamellar cataract & G91del & Reduced solubility & Qi et al., 2004; Reddy et al., 2004 \\
\hline$C R Y B A 1$ & & Cataract & Splicing intrin & n.d. & Burdon et al., 2004 \\
\hline CRYBB1 & & Pulverulent cataract & G220X & Reduced solubility & Mackay et al., 2002 \\
\hline \multirow[t]{2}{*}{ Crybb2 } & Philly & Progressive cataract & 12-bp deletion in exon 6 & 4th Greek Key motif & Chambers and Russell, 1991 \\
\hline & Aey2 & Progressive cataract & V187E & 4th Greek Key motif & Graw et al., 2001c \\
\hline$C R Y B B 2$ & & Cerulean cataract & Q155X & n.d. & Litt et al., 1997 \\
\hline$C R Y B B 2$ & & Coppock-like cataract & Q155X & n.d. & Gill et al., 2000 \\
\hline CRYBB2 & & Suture cataract and cerulean opacity & Q155X & n.d. & Vanita et al., 2001 \\
\hline$C R Y B B 2$ & & Central nuclear cataract & W151C & Loss of solubility? & Santhiya et al., 2004 \\
\hline $\begin{array}{l}\text { Cryga-f } \\
\text { CRYGC }\end{array}$ & Several alleles in mouse & $\begin{array}{l}\text { Various types of cataract } \\
\text { Coppock-like cataract }\end{array}$ & $\begin{array}{c}\text { Missense, nonsense, deletion/insertion } \\
\text { T5P }\end{array}$ & $\begin{array}{l}\text { Mainly Greek Key motifs affected } \\
\text { Impairment of folding }\end{array}$ & $\begin{array}{l}\text { See overview in Graw et al., 2004* } \\
\text { Héon et al., } 1999\end{array}$ \\
\hline CRYGC & & Zonular-pulverulent cataract & Insertion, 52 new amino acids & Hybrid protein & Ren et al., 2000 \\
\hline CRYGC & & Lamellar cataract & R168W & 4th Greek Key motif & Santhiya et al., 2002 \\
\hline CRYGD & & Punctate progressive cataract & $\mathrm{R} 14 \mathrm{C}$ & Altered surface properties & Stephan et al., 1999 \\
\hline$C R Y G D$ & & Lamellar cataract & Р23Т & n.d. & Santhiya et al., 2002 \\
\hline CRYGD & & Cerulean cataract & Р23Т & it Greek Key Motif, altered folding \& solubility & Nandrot et al., 2003 \\
\hline CRYGD & & Cataract & Р23Т & n.d. & Burdon et al., 2004 \\
\hline CRYGD & & Coral-shaped cataract & Р23Т & Less soluble & Mackay et al., 2004 \\
\hline CRYGD & & Fasciculiform cataract & Р23Т & n.d. & Shentu et al., 2004 \\
\hline CRYGD & & Prismatic crystals & $\mathrm{R} 36 \mathrm{C}$ & crystallization & Kmoch et al., 2000 \\
\hline CRYGD & & Aculeiform cataract & $\mathrm{R} 58 \mathrm{H}$ & Impairment of folding & Héon et al., 1999 \\
\hline CRYGD & & Central-nuclear & W158X & 4th Greek Key motif & Santhiya et al., 2002 \\
\hline \multirow[t]{2}{*}{ Bfsp2 } & $B f s p 2^{\prime}$ & Subtle loss of lens clarity & Targeted deletion & Loss of function & $\begin{array}{l}\text { Alizadeh et al., 2002; } \\
\text { Sandilands et al., } 2003\end{array}$ \\
\hline & Dundee & Subtle loss of lens clarity & Splicing defect & Loss of function & Sandilands et al., 2004 \\
\hline \multirow[t]{2}{*}{ BFSP2 } & & Juvenile onset cataract & R287W & Central rod domain & Conley et al., 2000 \\
\hline & & Nuclear cataract to spokelike opacity & $\Delta \mathrm{E} 233$ & Central rod domain & Jakobs et al., 2000 \\
\hline
\end{tabular}

n.d., not determined (or not reported); ${ }^{*}$ In this reference, 20 mutations in mouse Cryg genes are discussed. 
sible for this feature (Vanita et al., 2001; Gill et al., 2000). However, this does not explain the different cataract phenotypes.

Among the $\beta$-crystallin encoding genes, Cryba 1 is the secondmost one affected by cataract-causing mutations. It codes for two $\beta$-crystallins, $\beta A 1$ - and $\beta A 3$-crystallin, which differ by the length of their N-terminal extension (Peterson and Piatigorsky, 1986). In mouse, just one Cryba 1 mutation has been described (progressive opacity, po), which has a similar phenotype like the murine Crybb2 mutations cited above (Graw et al., 1999). Surprisingly, in human two independent mutations affect the same $5^{\prime}$ (donor) splice site of intron 3: in the first case, it is a $G \rightarrow A$ transition (Kannabiran et al., 1998), and in the second case a $\mathrm{G} \rightarrow \mathrm{C}$ transversion (Bateman et al., 2000). Unfortunately, since human lens cDNA was not available, the novel splice product could not be characterized. The phenotype was described as zonular cataract with sutural opacity (Kannabiran et al., 1998) or pulverulent, star-shaped or radial opacity (Bateman etal., 2000). The third mutation was reported just recently (Reddy et al., 2004) as a G91 deletion causing a lamellar cataract with variable severity in a five-generation family.

Another example of $C R Y B$ mutations concerns $C R Y B B 1$; in this gene a nonsense mutation (G220X) is associated with a fine, dustlike opacity affecting mainly the central zone of the lens (Mackay et al., 2002).

\section{The $\gamma$-crystallins}

An intermediate member of the $\beta / \gamma$-crystallin superfamily is the $\gamma S$-crystallin, previously also referred to as $\beta S$-crystallin. The corresponding gene Crygs was mapped to mouse chromosome 16 (Sinha et al., 1998). The cataract mutation opj (opacity due to poor juntions) (Everett et al., 1994; Kerscher et al., 1996) was mapped close to Crygs. Sequence analysis of Crygs from Opj mice revealed a mutation coding for a key residue of the core of the N-terminal domain of the protein (Wistow et al., 1998). Moreover, the first recessive mutation in mouse Cryg is characterized by a stop codon leading to a truncated protein that is missing 16 amino acids at the $C$ terminus in the mouse Crygs gene (Bu et al., 2002b).

The other six Cryg genes are organized as a cluster of very similar genes (Cryga $>$ Crygf) within approximately $50 \mathrm{~kb}$ on mouse chromosome 1. In mice, mutations have been characterized affecting all of these 6 genes; however, it is apparent that Cryge has the highest mutation frequency. An overview about the 20 characterized mouse mutants has been published recently (Graw et al., 2004). The first mutant, which was identified in this field is the Elomutant (Eye lens obsolescence; Oda et al., 1980); it was characterized by a single nucleotide deletion in the Cryge gene. The mutation destroys the reading frame of the gene, and at the protein level one of the Greek key motifs is affected (Cartier et al., 1992). Therefore, the new allele symbol is Cryge elo. One of the cataract mutants being most characterized among this group was originally referred to as Nop (nuclear opacity). It was of spontaneous origin (Graw et al., 1984) and shown to be caused by a small deletion of $11 \mathrm{bp}$ and an insertion of $4 \mathrm{bp}$ in the $3 \mathrm{rd}$ exon of the Crygb gene (novel allele symbol: Cryg $b^{\text {nop }}$ ). It leads to a frame shift and creates finally a new stop codon; the corresponding $\gamma \mathrm{B}$-crystallin protein is predicted to be truncated after 144 amino acids; the last six amino acids are different from the wildtype $\gamma \mathrm{B}$-crystallin. Western blot analysis demonstrated the stable expression of the wrong protein (Klopp et al., 1998).
Using in situhybridization techniques with a probe detecting all Cryg transcripts in embryonic sections, a lower extent of Cryg transcripts was detected in the $C r y g b^{n o p}$ mutants beginning from embryonic day 13.5. The first morphological abnormality in the mutant lenses was observed as swelling of lens fibers at embryonic day 15.5 (Santhiya et al., 1995).

The nuclei of the cortical cells could also be detected in the area of the lens nucleus of the Cryg ${ }^{n o p}$ and Cryge $e^{t}$ lenses (Graw et al., 1990a; 1990c). Biochemical investigations demonstrated an increase in the concentration of oxidized glutathione in the Crygb nop lenses over the wild type, which is not due to a corresponding decrease of an enzyme related to this metabolite (Graw et al., 1985; 1989).

All these Crygmutations affect only the lens cells and no other part of the eye; however, the size of the entire eye is always smaller than the wild type. A common feature in three mutants investigated is the inhibition of a $\mathrm{Mg}^{2+}$-dependent $\mathrm{DNase}$ in the lens. The decrease of DNase activity followed the same directionality (Cryge $\left.{ }^{n s}>\mathrm{Cryg}^{n o p}>\mathrm{Cryg}^{\prime}\right)$ as the decrease in the relative content of water-soluble lens protein, which might be used as a rough indicator for the severity of cataractogenesis (Graw and Liebstein, 1993). Although Cryg-mutation mediated mechanisms of cataract formation are not yet fully understood, it is known that the mutations interfere with the breakdown of the lens fibre cell nuclei during terminal differentiation. The alteration of this process was recently demonstrated for three mouse Cryg mutants $C_{\text {Crygb }}^{\text {nop }}$, Cryge $^{e l o}$, Cryge $^{t}$ - in which it was shown that ultimately the mutant $\gamma$-crystallins contribute to the formation of amyloid-like fibers in the lens fiber cell nuclei (Sandilands et al., 2002).

Some of the inherited cataracts in man are also related to mutations in the crystallin-encoding genes. In humans, two of the six CRYGgenes on chromosome 2 are pseudogenes (Brakenhoff et al., 1994). The list of families with hereditary congenital dominant cataracts who carry mutations in the CRYGgenes is growing rapidly (see Table 2). Mutations associated with a clinical phenotype have been found up to now only in $C R Y G C$ and $C R Y G D$. There appear two remarkable features: first, the $C R Y G D$-P23T mutation was observed in five independent families from different continents and reported to be causative for phenotypically diverse cataractous features. It is obviously no SNP or common polymorphism, because some of the studies looked for this mutations not only in the healthy relatives, but also in 100 unaffected people. It might be somehow dependant on the sequence, because the wild-type sequence CCACCCCAA changes to CCACACCAA. The second point of interest is that one of the dominant human CRYGD mutations (W156X) is identical to the dominant mouse Lop12 mutation (Smith et al., 2000). In this case, 18 amino acids are missing at the $\mathrm{C}$-terminus and lead to a dominant phenotype (in contrast to the 16 amino acids that are missing in the $\gamma S$ crystallin, which lead to a recessive phenotype). The common single base-pair exchange is $\mathrm{G} \rightarrow \mathrm{A}$, which cannot be explained by a slippage mechanism during DNA replication.

\section{Cytoskeletal proteins}

Among the lens cytoskeletal proteins filensin, vimentin and CP49 (also referred to as phakinin or beaded filament structural protein 2), the CP49 seems to be very important for the lens, because it is the only one among these three, which is sensitive to the deletion or mutation of its gene (at least with respect for 
cataract formation). CP49 and filensin, together with $\alpha$-crystallins, have been shown to immunolocalize to unique cytoskeletal structures within the lens fiber cells known as beaded filaments. They are considered to be important in facilitating the chaperone activity of $\alpha$-crystallin assemblies. Mutations in CP49-encoding gene BFSP2 were shown to be responsible for dominant cataracts in human (Conley et al., 2000, Jakobs et al., 2000); their phenotypes, however, seem to be variable ranging from congenital nuclear, sutural or stellate cataracts to juvenile-onset cataracts.

In the mouse, the knockout of the corresponding gene does not lead to cataracts, even if the absence of CP49 causes a subtle loss of optical clarity in the lens (Alizadeh et al., 2002; Sandilands et al., 2003). Moreover, a deletion of the splice-acceptor site in exon 2 of the mouse Bfsp2 results in a splicing of exon 1 to exon 3 and causes a frameshift in the reading frame as well as the introduction of a stop codon at position 2 of exon 3 in the Bfsp2 transcript. The phenotype of this mutation is also subtle as described for the knockout of the entire gene. Since this mutation is present in several mouse strains (129, 101 and CBA), it might interfere with other mutations or targeted deletions and, therefore, it might have important implications for lens studies using these strains (Sandilands et al., 2004).

\section{Further congenital cataracts}

\section{Hyperferritinaemia and I/i-antigens}

Hereditary hyperferritinaemia-cataract syndrome (HHCS; OMIM \#600886) is a rare autosomal dominant condition identified by high serum ferritin levels with normal iron saturation and distinctive bilateral cataract. The elevated serum ferritin is due to various mutations in the iron-responsive element (IRE) of the /ferritingene, resulting in excessive I-ferritin production. The IRE in the ferritin mRNAs is a hairpin structure near the beginning of the 5'-untranslated region. Trans-acting iron-regulatory proteins bind this RNA element and decrease ferritin translation by competing for ribosome binding. An increase in iron decreases the binding of these proteins, relieving inhibition of ferritin mRNA translation and resulting in increased ferritin mRNA translation. Mutations in this structure interefer with this IRE-mediated regulation of ferritin synthesis and lead to persistent hyperferritinemia (Brooks et al., 2002).

The first reports concerning this topic started in 1995 (Beaumont et al., 1995; Girelli et al., 1995). In the meantime, further papers have been published (surprisingly, most of them came from Northern Italy, a few from other European countries, and one from Australia) demonstrating a variety of onset, severity and type of cataracts caused by these mutations. The onset of this type of cataract is in some cases also early in childhood, and therefore, this syndrome should be suspected and ferritin levels measured in all cases of cataract in children (Campagnoli et al., 2002). However, other genetic causes for hyperferritinaemia (like mutations in the gene coding for ferroportin) are not associated with cataracts (Cazzola et al., 2002). Actually, there is no mouse model available.

Just recently, it was reported that congenital cataracts might be associated with the adult iphenotype, which can be observed in healthy people only at the surface of fetal or neonatal red blood cells. The human $\mathrm{i}$ and I antigens are characterized as linear and branched repeats of $\mathrm{N}$-acetyllactosamine, respectively. Conversion of the $\mathrm{i}$ to the I structure requires I-branching beta-1,6-Nacetylglucosaminyltransferase activity. It has been noted that the null phenotype of $/$, the adult i phenotype, is associated with congenital cataracts mainly in Asians. The results suggest a molecular genetic mechanism that may explain the partial association of the adult i phenotype with congenital cataracts and indicate that a defect in the / locus may lead directly to the development of congenital cataracts (Yu et al., 2003).

\section{Mutants waiting for molecular characterization}

Besides the Mip/aquaporin cataracts, another group of cataract mutations is localized at mouse chromosome 10 , in this case $3.2 \mathrm{cM}$ proximal to $S /$ (Löster et al., 1997). It consists of two alleles and is provisionally referred to as Cat3(Kratochvilova and Favor, 1992). Cat3 ${ }^{\text {/l }}$ (vacuolated lens; Kratochvilova, 1981) and Cat3vao (cataract with anterior opacity; Graw et al., 1986) arose independently in the $F_{1}$ generation after paternal $\gamma$-irradiation. On the basis of the location of Cat3to this defined region of chromosome 10, several genes have been considered as candidates for Cat3, but none of them was confirmed as target of the mutations (Löster et al., 1997). To the region of conserved synteny at human chromosome 12q21-24 the human eye disorder cornea plana congenita has been mapped and shown to be caused by mutations in KERA, coding for keratocan (Pellegata et al., 2000).

Slit lamp observation revealed that the lenses of the Cat3 ${ }^{\mathrm{v}}$ mutants are filled up with small and large vacuoles. Pupillary dilatation is limited. The anterior chamber is flattened, and opacified corneas are frequently observed. The Cat3 ${ }^{\text {vao }}$ mutants show an opaque area immediately beneath the lenticular capsule forming multiple disk-like opacities around the optical axis. The two alleles differ mainly in the appearance of their opacities (Löster et al., 1997).

The histological analysis identified an aberrant cell layer between the anterior epithelium and the primary lens fibers at embryonic day $E 12.5$, when the lens vesicle is filled by the primary lens fibers. It leads to a maldevelopment of the anterior lens epithelium and degeneration of the fibers. After birth, the lens capsule ruptures at the equatorial region, and synechiae with the iris occur (Graw, 1999). Biochemical examination of the cataractous Cat3 vao lenses demonstrated the presence of oxidative and osmotic stress (Graw et al., 1989; 1990b).

The dominant X-linked cataract mutation Xcatwas recovered after parental radiation (Favor and Pretsch, 1990). Histological analysis during the embryonic development revealed that in the affected embryos the primary fiber cells are irregularly arranged and show small foci of cellular disintegration. Progressive degeneration of fibers occurs. However, the lens epithelium and the newly differentiated fibers show no evident abnormality indicating that the mutation affects the differentiation of the primary lens fiber cells after their initial elongation. Analysis of crystallin and cytoskeleton proteins of postnatal cataractous lenses revealed no significant abnormalities when compared to the normal lens (Grimes et al., 1993). Detailed genetical analysis placed the Xcat mutation to the distal end of the mouse $X$ chromosome. It suggests that this locus should map to a conserved block at Xp22.1-p22.3 in human. To this region, the Nance Horan Syndrome (NHS) has been mapped but the corresponding gene has been excluded as candidate (Stambolian et al., 1994) as well as 
Aphakia/Pitx3

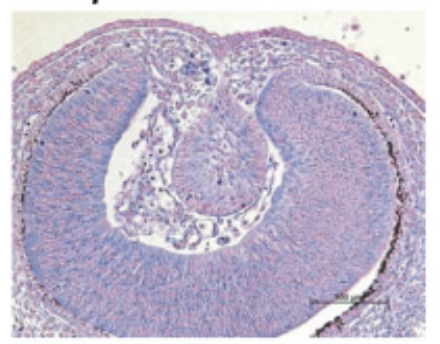

E10.5

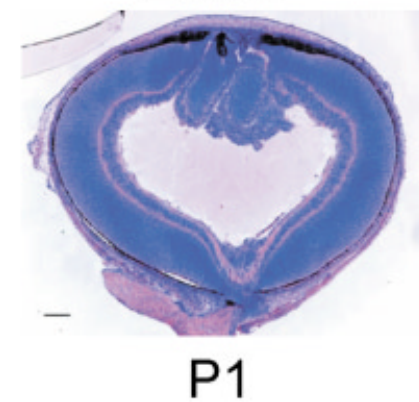

Aey12

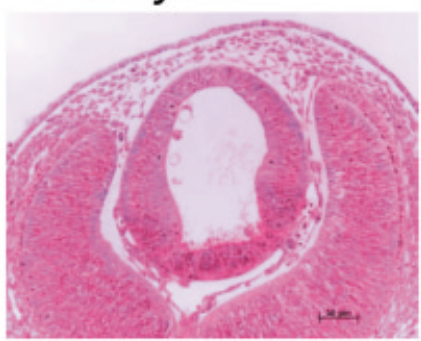

E12.5

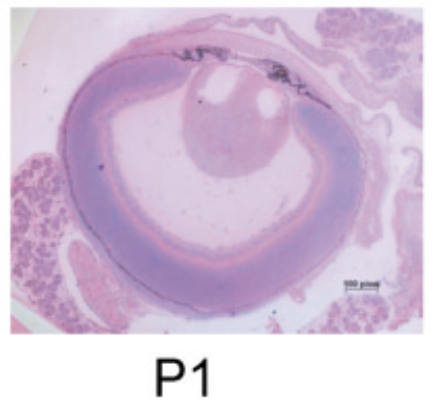

Cat3

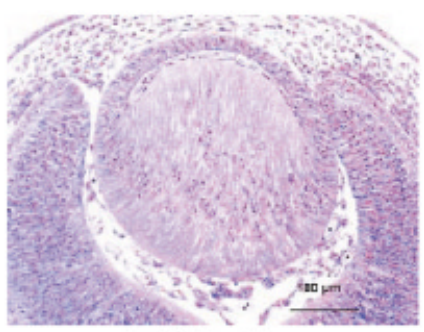

E12.5

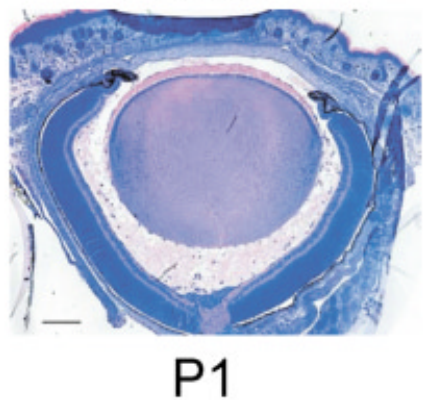

Crygb Nop

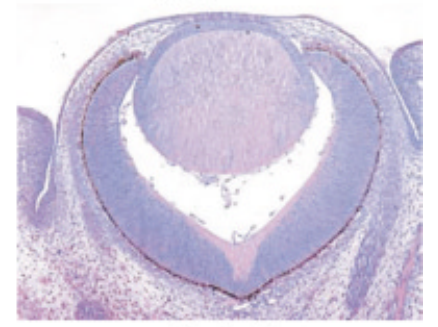

E14.5

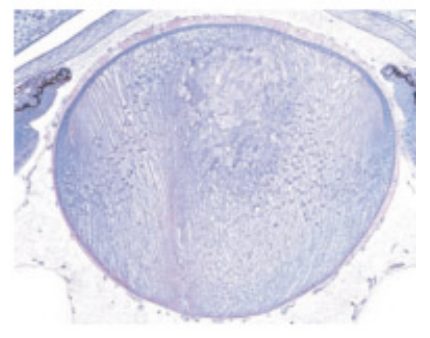

P1

Fig. 2. Overview on mutations affecting early development. Four different mutants are presented, which affect eye and lens development at different embryonic time points (E); for later comparison, in all cases neonatal eyes are shown: The aphakia/Pitx3 mutation stops eye development at the lens stalk stage, and leads finally to an overgrowth of the retina because of missing inhibitory signals from the lens; the unknown mutation in the Aey 12 stops lens development at the lens vesicle stage; retina differentiation is poor, and the iris covers the entire anterior segment; the unknown Cat3 mutation interferes with the secondary lens fiber cell differentiation and leads to vacuolisation of the lens; however, the retina differentiation is not affected; the Crgyb mutation Nop affects late lens development; there is no obvious defect in other ocular tissues.

some others (Zhou et al., 1995) Moreover, Francis et al., (2002) mapped an isolated cataract in man to the same chromosomal region.

Another X-linked mouse mutant with affected lenses is referred to as bare patches (Bpa). Since hemizygous males die before birth, heterozygous females have patches of bare skin. Lens cortical "frost figure" opacities are present. Bpa is considered as a model for human X-linked syndrome chondrodysplasia punctata (Happle et al., 1983; Angel et al., 1993).

The mutation vacuolatedlens $(v)$ is mapped to mouse chromosome 1 and leads to opaque white lenses. Additionally, the mutants are characterized by a white belly spot and spina bifida. Small lens vacuoles are present at birth (Dickie, 1967; 1969). The mutant blind-sterile ( $b s$ ) is characterized by bilateral nuclear cataracts, microphthalmia and glossy coats. The cataracts are detectable at E16. Females are fertile, but males are sterile. The mutation was mapped to mouse chromosome 2 (Varnum, 1983).

The Tcm mutation (total cataract with microphthalmia), a cataract with iris dysplasia and coloboma (Zhou et al., 1997) and the Ccwmutation, cataract and curly whiskers (Kerscher et al., 1996), are localized on mouse chromosome 4. The nuclear-posterior polar opacity (Npp) maps to chromosome 5, and Cat5 (previously To2), a total opacity, to chromosome 10 (Everett et al., 1994).

The so-called rupture of lens cataract $(r / c)$ was mapped to chromosome 14 (Matsushima et al., 1996) and a similar form, Ir2 (lens rupture 2) was mapped to a close position (Song et al., 1997). The opacity in the $r / d / r / c$ mice becomes apparent at 35-60 days of age; there are no developmental changes reported (lida et al., 1997). Another form of cataracts, which is formed postnatally without observed developmental alterations, is the Nakano cataract (nct, Takehana, 1990; Wada et al., 1991). The mutation was mapped to chromosome 16 (Hiai et al., 1998).

\section{Conclusion and perspectives}

A great variety of mouse mutants affecting ocular development is available. They arose spontaneously, or were recovered after parental treatment by chemical mutagens or radiation. Recent development of molecular methods is leading to a rapidly increasing number of transgenic mice overexpressing particular genes in distinct tissues or representing null alleles by targeted disruption of the genes. The molecular analysis of the affected genes together with the detailed phenotypical analysis, will allow us to understand the pathways of ocular development.

A first set of mutants might indicate the inverse relationship between lens and retina development. Fig. 2 shows four examples of mouse mutants with different onsets of morphological alterations in the lens starting with the aphakia mouse and its arresst at the lens stalk stage. In this case, the growth of the retina is obviously not limited, and after birth, retinal tissues fills the entire eye ball. In contrast, mutations affecting the Cryggenes affect the lens severely, however, the retina remains unaffected. The two other mutants with their major defects are laying between these two extremes - the Aey12 mutants with their arrest at the lens vesicle stage (Graw et al., 2003) or the Cat3 mutants with their problems in the initial phase of the secondary fiber cell formation (Löster etal., 1997) - have obviously smaller consequences for the retina development than the aphakia mouse.

The more detailed analysis of these mutants will enable us to describe also more precisely the mechanisms leading to the 
pathological situation. The mouse as one of the most important model systems in eye development is currently be supplemented by the rapidly increasing number of mutants in the zebrafish (Glass and Dahm, 2004). Together with modern techniques in biochemistry, it might become possible in the near future to treat at least some of the inherited ocular diseases either by novel drugs or by somatic gene therapy. For each of these steps, mouse mutants are an indispensible tool.

\section{References}

AGRE, P. and KOZONO, D. (2003) Aquaporin water channels: molecular mechanisms for human diseases. FEBS Lett. 555:72-78.

ALIZADEH, A., CLARK, J.I., SEEBERGER, T., HESS, J., BLANKENSHIP, T., SPICER, A. and FITZGERALD, P.G. (2002) Targeted genomic deletion of the lens-specific intermediate filament protein CP49. Invest. Ophthalmol. Vis. Sci. 43: 3722-3727

ANGEL, T.A., FAUST, C.J., GONZALES, J.C., KENWRICK, S., LEWIS, R.A. and HERMAN, G.E. (1993) Genetic mapping of the X-linked dominant mutations striated (Str) and bare patches (Bpa) to a 600-kb region of the mouse Xchromosome: implications for mapping human disorders in Xq28. Mamm Genome 4: 171-176.

ASO, S., HORIWAKI, S.I. and NODA, S. (1995) Lens aplasia: a new mutation producing lens abnormality in the mouse. Lab Anim Sci 45: 41-46.

ASO, S., TASHIRO, M., BABA, R., SAWAKI, M., NODA, S. and FUJITA, M. (1998) Apoptosis in the lens anlage of the heritable lens aplastic mouse (lap mouse). Teratology 58: 44-53.

AVILION, A.A., NICOLIS, S.K., PEVNY, L.H., PEREZ, L., VIVIAN, N. and LOVELLBADGE, R. (2003) Multipotent cell lineages in early mouse development depend on SOX2 function. Genes Dev17: 136-140

AZUMA, N., HIRAKYAMA, A., INOUE, T., ASAKA, A. and YAMADA, M. (2000) Mutations of a human homologue to the Drosophila eyes absent gene (EYA1) detected in patients with congenital cataracts and ocular anterior segment anomalies. Hum. Mol. Genet. 9: 363-366.

BATEMAN, J.B., GEYER, D.D., FLODMAN, P., JOHANNES, M., SIKELA, J., WALTER, N., MOREIRA, A.T., CLANCY, K. and SPENCE, M.A. (2000) A new $\beta$ A1-crystallin splice junction mutation in autosomal dominant cataract. Invest. Ophthalmol. Vis. Sci. 41: 3278-3285.

BEAUMONT, C., LENEUVE, P., DEVAUX, I., SCOAZEC, JY, BERTHIER, M., LOISEAU, M.N., GRANDCHAMP, B. and BONNEAU, D. (1995) Mutation in the iron responsive element of the $L$ ferritin mRNA in a family with dominant hyperferritinaemia and cataract. Nat. Genet. 11:444-446.

BERRY, V., FRANCIS, P., KAUSHAL, S., MOORE, A. and BHATTACHARYA, S. (2000) Missense mutations in MIP underlie autosomal dominant «polymorphic» and lamellar cataracts linked to 12q. Nat. Genet. 25: 15-17.

BERRY, V., FRANCIS, P., REDDY, M.A., COLLYER, D., VITHANA, E., MACKAY, I., DAWSON, G., CAREY, A.H., MOORE, A., BHATTACHARYA, S.S. and QUINLAN R.A. (2001) Alpha-B-crystallin gene ( $C R Y A B)$ mutation causes dominant congenital posterior polar cataract in humans. Am. J. Hum. Genet. 69: 1141-1145.

BERRY, V., MACKAY, D., KHALIQ, S., FRANCIS, P.J., HAMEED, A., ANWAR, K., MEHDI, S.Q., NEWBOLD, R.J., IONIDES, A., SHIELS, A., MOORE, T. and BHATTACHARYA, S.S. (1999) Connexin 50 mutation in a family with congenital "zonular nuclear" pulverulent cataract of Pakistani origin. Hum. Genet. 105: 168170.

BHAT, S.P. (2003) Crystallins, genes and cataract. Progr. Drug Res. 60:207-262.

BLIXT, A., MAHLAPUU, M., AITOLA, M., PELTO-HUIKKO, M., ENERBÄK, S. and CARLSSON, P. (2000) A forkhead gene, FOXE3, is essential for lens epithelial proliferation and closure of the lens vesicle. Genes Dev. 14: 245-254.

BOVA, M.P., YARON, O., HUANG, Q., DING, L., HALEY, D.A., STEWART, P.L. and Horwitz, J. (1999) Mutation R120G in $\alpha$ B-crystallin, which is linked to a desmin-related myopathy, results in an irregular structure and defective chaperone-like function. Proc. Natl. Acad. Sci. USA 96:6137-6142.

BRADY, J.P., GARLAND, D., DUGLAS-TABOR, Y., ROBISON, W.G.JR., GROOME, A. and WAWROUSEK, E.F. (1997) Targeted disruption of the mouse $\alpha A$ crystallin gene induces cataract and cytoplasmic inclusion bodies containing the small heat shock protein $\alpha$ B-crystallin. Proc Nat/Acad SciUSA94: 884-889.
BRADY, J.P., GARLAND, D.L., GREEN, D.E., TAMM, E.R., GIBLIN, F.J. and WAWROUSEK, E.F. (2001) $\alpha$ B-crystallin in lens development and muscle integrity: a gene knockout approach. Invest. Ophthalmol. Vis. Sci. 42, 2924-2934.

BRAKENHOFF, R.H., HENSKENS, H.A.M., VAN ROSSUM, M.W.P.C. and LUBSEN, N.H., SCHOENMAKERS, J.G.G. (1994) Activation of the $\gamma E$-crystallin pseudogene in the human hereditary Coppock-like cataract. Hum Mol Genet 3: 279-283.

BROOKS, D.G., MANOVA-TODOROVA, K., FARMER, J., LOBMAYR, L., WILSON, R.B., EAGLE, R.C.jr., ST.PIERRE, T.G. and STAMBOLIAN, D. (2002) Ferritin crystal cataracts in hereditary hyperferritinemia cataract syndrome. Invest. Ophthalmol. Vis. Sci. 43:1121-1126.

BU, L., JIN, Y., SHI, Y., CHU, R., BAN, A., EIBERG, H., ANDRES, L., JIANG, H. ZHENG, G., QIAN, M., CUI, B., XIA, Y., LIU, J., HU, L., ZHAO, G., HAYDEN, M.R and KONG, X. (2002a) Mutant DNA-binding domain of HSF4 is associated with autosomal dominant lamellar and Marner cataract. Nat. Genet. 31: 276-278.

BU, L., YAN, S., JIN, M., JIN, Y., YU, C., XIAO, S., XIE, Q., HU, L., XIE, Y, SOLITANG, Y., LIU, J., ZHAO, G. and KONG, X. (2002b) The $\gamma$ S-crystallin gene is mutated in autosomal recessive cataract in mouse. Genomics 80, 38-44.

BURDON, K.P., WIRTH, M.G., MACKAY, D.A., RUSSELL-EGGITT, I.M., CRAIG, J.E., ELDER, J.E., DICKINSON, J.L. and SALE, M.M. (2004) Investigation of crystallin genes in familial cataract, and report of two disease associated mutations. Br. J. Ophthalmol. 88:79-83.

CAMPAGNOLI, M., PIMAZZONI, R., BOSIO, S., ZECCHINA, G., DEGOBBI, M. BOSSO, P., OLDANI, B. and RAMENGHI, U. (2002) Onset of cataract in early infancy associated with a $32 \mathrm{G} \rightarrow \mathrm{C}$ transition in the iron responsive element of $\mathrm{L}$ ferritin. Eur J Paediatr. 161: 499-502

CARPER, D., SHINOHARA, T., PIATIGORSKY, J. and KINOSHITA, J.H. (1982) Deficiency of functional messenger RNA for a developmentally regulated $\beta$ crystallin polypeptide in a hereditary cataract. Science 217: 463-464

CARTIER, M., BREITMAN, M.L. and TSUI, L.C. (1992) A frameshift mutation in the $\gamma E-$ crystallin gene of the Elo mouse. Nat Genet 2: 42-45.

CAZZOLA, M., CREMONESI, L., PAPAIOANNOU, M., SORIANI, N., KIOUMI, A. CHARALAMBIDOU, A., PARONI, R., ROMTSOU, K., LEVI, S., FERRARI, M., AROSIO, P. and CHRISTAKIS, J. (2002) Genetic hyperferritinaemia and reticuloendothelial iron overload associated with a three base pair deletion in the coding region of the ferroprotein gene (SLC11A3). Br J Haematol. 119: 539-546

CENTER, E.M. and POLIZZOTTO, R.S. (1992) Etiology of the developing eye in myelencephalic blebs (my) mice. Histol Histopatho/7: 231-236.

CHAMBERS, C. and RUSSELL, P. (1991) Deletion mutation in an eye lens $\beta$-crystallin. $\checkmark$ Biol Chem 266: 6742-6746.

CHANG, B., HAWES, N.L., RODERICK, T.H., SMITH, R.S., HECKENLIVELY, J.R., HORWITZ, J. and DAVISSON, M.T. (1999) Identification of a missense mutation in the $\alpha \mathrm{A}$-crystallin gene of the lop18mouse. Mol. Vis. 5, 21 .

COBB, B.A. and PETRASH, J.M. (2000) Structural and functional changes in the $\alpha A$ crystallin R116C mutant in hereditary cataracts. Biochemistry39: 15791-15798.

CONLEY, Y.P., ERTURK, D., KEVERLINE, A., MAH, T.S., KERAVALA, A., BARNES, L.R., BRUCHIS, A., HESS, J.F., FITZGERALD, P.G., WEEKS, D.E., FERRELL, R.E., and GORIN, M.B. (2000) A juvenile-onset, progressive cataract locus on chromosome $3 q 21-q 22$ is associated with a missense mutation in the beaded filament structural protein-2. Am. J. Hum. Genet. 66: 1426-1431.

DAHM, R., VAN MARLE, J., PRESCOTT, A.R. and QUINLAN, R.A. (1999) Gap junctions containing $\alpha 8$-connexin (MP70) in the adult mammalian lens epithelium suggests a re-evaluation of its role in the lens. Exp Eye Res. 69: 45-56

DICKIE, M.M. (1967) Vacuolated lens. Mouse News Lett 36: 39-40.

DICKIE, M.M. (1969) Vacuolated lens (v). Mouse News Lett 40: 29.

EHLING, U.H., CHARLES, D.J., FAVOR, J., GRAW, J., KRATOCHVILOVA, J., NEUHÄUSER-KLAUS, A. and PRETSCH, W. (1985) Induction of gene mutations in mice: the multiple endpoint approach. Mutat Res 150: 393-401.

EVERETT, C.A., GLENISTER, P.H., TAYLOR, D.M., LYON, M.F., KRATOCHVILOVA-LÖSTER, J. and FAVOR, J. (1994) Mapping of six dominant cataract genes in the mouse. Genomics 20: 429-434.

FANTES, J, RAGGE, N.K., LYNCH, S.-A., MCGILL, N.I., COLLIN, J.R.O., HOWARD PEEBLES, P.N., HAYWARD, C., VIVIAN, A.J., WILLIAMSON, K., VAN HEYNINGEN, V. and FITZPATRICK, D.R. (2003) Mutations in SOX2 cause anophthalmia. Nat. Genet. 33, 1-2.

FAVOR. J. (1995) Mutagenesis and human genetic disease: dominant mutation frequencies and a characterization of mutational events in mice and humans. Environ Mol Mutagen 25 (S26): 81-87 
FAVOR, J., GRIMES, P., NEUHÄUSER-KLAUS, A., PRETSCH, W. and STAMBOLIAN, D. (1997) The mouse Cat4 locus maps to chromosome 8 and mutants express lens-corneal adhesion. Mamm Genome 8: 403-406.

FAVOR, J., PETERS, H., HERMANN, T., SCHMAHL, W., CHATTERJEE, B., NEUHÄUSER-KLAUS, A. and SANDULACHE, R. (2001) Molecular characterization of PaxG ${ }^{2 N e u}$ through PaxG ${ }^{10 N e u}$ : An extension of the PaxG allelic series and the identification of two possible hypomorph alleles in the mouse Mus musculus. Genetics 159: 1689-1700.

FAVOR, J. and PRETSCH, W. (1990) Genetic localization and phenotypic expression of X-linked cataract (Xcat) in Mus musculus. Genet Res Camb56: 157-162.

FOSTER, A., GILBERT, C. and RAHI, J. (1997) Epidemiology of cataract in childhood: a global perspective. J Cataract Refract Surg. 23 (Suppl. 1): 601-604.

FRANCIS, P.J., BERRY, V., HARDCASTLE, A.J., MAHER, E.R., MOORE, A.T. and BATTACHARYA, S.S. (2002) A locus for isolated cataract on human Xp. JMed Genet 39: 105-109

FRANZ, T. and BESECKE, A. (1991) The development of the eye in homozygotes of the mouse mutant Extra-toes. Anat Embryol 184: 355-361.

FRASER, F.C. and SCHABTACH, G. (1962) "shrivelled": a hereditary degeneration of the lens in the house mouse. Genet Res Camb3: 383-387.

GAO, Y. and SPRAY, D.C. (1998) Structural changes in lenses of mice lacking the gap junction protein connexin43. Invest Ophthalmol Visual Sci39: 1198-1209.

GILL, D., KLOSE, R., MUNIER, F.L., MCFADDEN, M., PRISTON, M., BILLINGSLEY, G., DUCREY, N., SCHORDERET, D.F. and HÉON, E. (2000) Genetic heterogeneity of the Coppock-like cataract: a mutation in CRYBB2 on chromosome 22q11.2. Invest. Ophthalmol. Vis. Sci. 41: 159-165.

GIRELLI, D., CORROCHER, R., BISCEGLIA, L., OLIVIERI, O., DE FRANCESCHI, L., ZELANTE, L. and GASPARINI, P. (1995) Molecular basis for the recently described hereditary hyperferritinemia-cataract syndrome: a mutation in the iron-responsive element of ferritin L-subunit gene (the "Verona mutation»). Blood 86: 4050-4053.

GLASER, T., JEPEAL L., EDWARDS, J.G., YOUNG, S.R., FAVOR, J. and MAAS, R.L. (1994) PAX6gene dosage effect in a family with congenital cataracts, aniridia, anophthalmia and central nervous system defects. Nat. Genet. 7: 463-471.

GLASS, A.S. and DAHM, R. (2004) The zebrafish as a model organism for eye development. Ophthal. Res. 36: 4-24.

GONG, X., LI, E., KLIER, G., HUANG, Q., WU, Y., LEI, H., KUMAR, N.M., HORWITZ, J. and GILULA, N.B. (1997) Disruption of $\alpha 3$ connexingene leads to proteolysis and cataractogenesis in mice. Cel/91: 833-843.

GRAW, J. (1997) The crystallins: genes, proteins and diseases. Biol Chem 378: 1331-1348.

GRAW, J. (1999) Cataract mutations and lens development. Progr Retin Eye Res. 18: $235-267$

GRAW, J. (2003) The genetic and molecular basis of congenital eye defects. Nat. Rev. Genet. 4: 877-888.

GRAW, J. and LIEBSTEIN, A. (1993) DNase activity in murine lenses: implications for cataractogenesis. Graefe's Arch Clin Exp Ophthalmo/231: 354-358.

GRAW, J. and LÖSTER, J. (2003) Developmental genetics in Ophthalmology. Ophthal Genet 24: 1-33.

GRAW, J., BORS, W., GOPINATH, P.M., MERKLE, S., MICHEL, C., REITMEIR, P., SCHÄFFER, E., SUMMER, K.H. and WULFF, A. (1990a) Characterization of Cat-2t, a radiation-induced dominant cataract mutation in mice. Invest. Ophthalmol. Vis. Sci. 31: 1353-1361.

GRAW, J., BORS, W., MICHEL, C., REITMEIR, P., SUMMER K.H. and WULFF, A. (1989) Oxidative stress and inherited cataracts in mice. Ophthalmic Res. 21: 414-419.

GRAW, J., FAVOR, J., NEUHÄUSER-KLAUS, A. and EHLING, U.H. (1986) Dominant cataract and recessive specific locus mutations in offspring of $X$ irradiated male mice. Mutat. Res. 159: 47-54.

GRAW, J., JUNG, M., LÖSTER, J., KLOPP, N., SOEWARTO, D., FELLA, C., FUCHS, H., REIS, A., WOLF, E., BALLING, R. and HRABÉ DE ANGELIS, M. (1999) Mutation in the $\beta A 3 / A 1$-crystallin encoding gene Cryba1 causes a dominant cataract in the mouse. Genomics 62: 67-73.

GRAW, J., KRATOCHVILOVA, J. and SUMMER, K.H. (1984) Genetical and biochemical studies of a dominant cataract mutant in mice. Exp. Eye Res. 39: $37-45$.
GRAW, J., LÖSTER, J., MEYER, B., NÜRNBERG, P., SOEWARTO, D. and FUCHS, H. (2003) Aey12, a new mutation on mouse chromosome 10 shows a phenotype similar to Maf mutants. Ophthal. Res. 35 (S1): 198.

GRAW, J., LÖSTER, J., SOEWARTO, D., FUCHS, H., MEYER, B., REIS, A., WOLF, E., BALLING, R. and HRABÉ DE ANGELIS, M. (2001a) Characterization of a new, dominant V124E mutation in the mouse $\alpha A$-crystallin encoding gene. Invest Ophthalmol Vis Sci42:2909-2915.

GRAW, J., LÖSTER, J., SOEWARTO, D., FUCHS, H., MEYER, B., REIS, A., WOLF, E., BALLING, R. and HRABÉ DE ANGELIS, M. (2001b) Characterization of a mutation in the lens-specific MP70 encoding gene of the mouse leading to a dominant cataract. Exp. Eye Res. 73:867-876.

GRAW, J., LÖSTER, J., SOEWARTO, D., FUCHS, H.,REIS, A., WOLF, E., BALLING, R. and HRABÉ DE ANGELIS, M. (2001c) Aey2, a new mutation in the BB2-crystallin encoding gene in the mouse. Invest. Ophthalmol. Vis. Sci. 42:1574-1580.

GRAW, J., NEUHÄUSER-KLAUS, A., KLOPP, N., SELBY, P.B., LÖSTER, J. and FAVOR, J. (2004) Genetic and allelic heterogeneity of Cryg mutations in eight distinct forms of dominant cataract in the mouse. Invest. Ophthalmol. Vis. Sci. 45:1202-1213.

GRAW, J., REITMEIR, P. and WULFF, A. (1990b) Osmotic state of lenses in three dominant murine cataract mutants. Graefe's Arch. Clin. Exp. Ophthalmol. 228: 252-254.

GRAW, J., SUMMER, K.H., MICHEL, C. and BORS, W. (1985) Catalase and superoxide dismutase activities in lenses of cataractous NOP-mice. Exp. Eye Res. 41: 577-579.

GRAW, J., WERNER, T., MERKLE, S., REITMEIR, P., SCHÄFFER, E. and WULFF, A. (1990c) Histological and biochemical characterization of the murine cataract mutant Nop. Exp. Eye Res. 50: 449-456.

GRIFFIN, C.S. and SHIELS, A. (1992) Localisation of the gene for the major intrinsic protein of eye-lens-fibre cell membranes to mouse Chromosome 10 by in situ hybridisation. Cytogenet. Cell Genet. 59: 300-302.

GRIMES, P.A., FAVOR, J., KOEBERLEIN, B., SILVERS, W.K., FITZGERALD, P.G. and STAMBOLIAN, D. (1993) Lens development in a dominant X-linked congenital cataract of the mouse. Exp. Eye Res. 57: 587-594.

GRIMES, P.A., KOEBERLEIN, B., FAVOR, J., NEUHÄUSER-KLAUS, A. and STAMBOLIAN, D. (1998) Abnormal eye development associated with Cat4a, a dominant mouse cataract mutation on chromosome 8. Invest. Ophthalmol. Vis. Sci. 39: 1863-1869.

HAEFLINGER, J.A., BRUZZONE, R., JENKINS, N.A., GILBERT, D.J., COPELAND, N.G. and PAUL, D.L. (1992) Four novel members of the connexin family of gap junction proteins. Molecular cloning, expression, and chromosome mapping. J. Biol. Chem. 267: 2057-2064.

HANSON, I. and VAN HEYNINGEN, V. (1995) Pax6: more than meets the eye. Trends Genet. 11: 268-272.

HANSON, I., CHURCHILL, A., LOVE, J., AXTON, R., MOORE, T., CLARKE, M., MEIRE, F. and VAN HEYNINGEN, V. (1999) Missense mutations in the most ancient residues of the PAX6 paired domain underlie a spectrum of human congenital eye malformations. Hum. Mol. Genet. 8, 165-172.

HAPPLE, R., PHILLIPS, R.J., ROESSNER, A. and JUNEMANN, G. (1983) Homologous genes for X-linked chondrodysplasia punctata in man and mouse. Hum Genet. 63: 24-27.

HÉON, E., PRISTON, M., SCHORDERET, D.F., BILLINGSLEY, G.D., GIRARD, P.O., LUBSEN, N. and MUNIER, F.L. (1999) The $\gamma$-crystallins and human cataracts: a puzzle made clearer. Am. J. Hum. Mol. Genet. 65: 1261-1267.

HIAI, H., KATO, S., HORIUCHI, Y., SHIMADA, R., TSURUYAMA, T., WATANABE, T. and MATSUZAWA, A. (1998) Mapping of Nakanocataract gene ncton mouse chromosome 16. Genomics 50: 119-120.

HILL, R.E., FAVOR, J., HOGAN, B.L.M., TON, C.C.T., SAUNDERS, G.F., HANSON, I.M., PROSSER, J., JORDAN, T., HASTIE, N.D. and VAN HEYNINGEN, V. (1991) Mouse Small eye results from mutations in a paired-like homeoboxcontaining gene. Nature 354: 522-525.

HOGAN, B.L.M., HORSBURGH, G., COHEN, J., HETHERINGTON, C.M., FISHER, G. and LYON, M.F. (1986) Small eyes (Sey): a homozygous lethal mutation on chromosome 2 which affects the differentiation of both lens and nasal placodes in the mouse. J. Embryol. Exp. Morphol. 97: 95-110. 
HOGAN, B.L.M., HIRST, E.M.A., HORSBURGH, G. and HETHERINGTON, C.M. (1988) Small eye (Sey): a mouse model for the genetic analysis of craniofacial abnormalities. Development 103 (Suppl): 115-119.

HONG, H.K., LASS, J.H. and CHAKRAVARTI, A. (1999) Pleiotropic skeletal and ocular phenotypes of the mouse mutation congenital hydrocephalus (ch/Mft) arise frome a winged helix/forkhead transcription factor gene. Hum. Mol. Genet. 8:625-637.

HSIEH, C.L., KUMAR, N.M., GILULA, N.B. and FRANCKE, U. (1991) Distribution of genes for gap junction membrane channel proteins on human and mouse chromosomes. Somat. Cell. Mol. Genet. 17: 1991-200.

HUI, C.C. and JOYNER, A.L. (1993) A mouse model of greig cephalopolysyndactyly syndrome: the extra-toes ${ }^{J}$ mutation contains an intragenic deletion of the Gli3 gene. Nat. Genet. 3: 241-246.

HWANG, D.Y., ARDAYFIO, P., KANG, U.J., SEMINA, E.V. and KIM, K.S. (2003) Selective loss of dopaminergic neurons in the substantia nigra of Pitx3-deficient aphakia mice. Mol. Brain Res. 114: 123-131

IIDA, F., MATSUSHIMA, Y., HIAI, H., UGA, S. and HONDA, Y. (1997) Rupture of lens cataract: a novel hereditary recessive cataract model in the mouse. Exp. Eye Res. 64: 107-113.

JAKOBS, P.M., HESS, J.F., FITZGERALD, P.G., KRAMER, P., WELEBER, R.G. and LITT, M. (2000) Autosomal-dominant congenital cataract associated with a deletion mutation in the human beaded filament protein BFSP2. Am. J. Hum. Genet. 66: 1432-1436.

JAMIESON, R.V., PERVEEN, R., KERR, B., CARETTE, M., YARDLEY, J., HÉON, E., WIRTH, M.G., VAN HEYNINGEN, V., DONNAI, D., MUNIER, F. and BLACK, G.C.M. (2002) Domain disruption and mutation of the bZIP transcription factor, MAF, associated with cataract, ocular anterior segment dysgenesis and coloboma. Hum. Mol. Genet. 11, 33-42.

JIANG, H., JIN, Y., BU, L., ZHANG, W., LIU, J., CUI, B., KONG, X. and HU, L. (2003) A novel mutation in $G J A 3$ (connexin46) for autosomal dominant congenital nuclear pulverulent cataract. Mol. Vis. 9: 579-583.

KADOR, P.F., FUKUI, H.N., FUKUSHI, S., JERNIGAN, H.M.JR. and KINOSHITA, J.H. (1980) Philly mouse: a new model of hereditary cataract. Exp. Eye Res. 30: 59-68.

KAMACHI, Y., UCHIKAWA, M., COLLIGNON, J., LOVELL-BADGE, R. and $\mathrm{KONDOH}, \mathrm{H}$. (1998) Involvement of Sox1, 2 and 3 in the early and subsequent molecular events of lens induction. Development 125: 2521-2532.

KAMACHI, Y., UCHIKAWA, M. and KONDOH, H. (2000) Pairing SOX off with partners in the regulation of embryonic development. Trends Genet. 16: 182-187.

KANNABIRAN, C., ROGAN, P.K., OLMOS, L., BASTI, S., RAO, G.N., KAISERKUPFER, M. and HEJTMANCIK, J.F. (1998) Autosomal dominant zonular cataract with sutural opacities is associated with a splice mutation in the $\beta A 3 /$ A1-crystallin gene. Mol. Vis. 4:18

KATAOKA, K., NISHIZAWA, M. and KAWAI, S. (1993) Structure-function analysis of the maf oncogene product, a member of the b-Zip protein family. J. Virol. 67: 2133-2141.

KATAOKA, K., NODA, M. and NISHIZAWA, M. (1996) Transactivation activity of Maf nuclear oncoprotein is modulated by Jun, Fos and small Maf proteins. Oncogene 12: 53-62.

KERSCHER, S., CHURCH, R.L., BOYD, Y. and LYON, M.F. (1995) Mapping of four mouse genes encoding eye lens-specific structural, gap junction, and integral membrane proteins: Cryba1 (crystallin $\beta A 3 / A 1)$, Crybb2 (crystallin $\beta B 2)$, Gja8 (MP70), and Lim2 (MP19). Genomics 29: 445-450.

KERSCHER, S., GLENISTER, P.H., FAVOR, J. and LYON, M.F (1996) Two new cataract loci, CCW and To3, and further mapping of the Npp and Opjcataracts in the mouse. Genomics 36: 17-21.

KLOPP, N., FAVOR, J., LÖSTER, J., LUTZ, R.B., NEUHÄUSER-KLAUS, A., PRESCOTT, A., PRETSCH, W., QUINLAN, R.A., SANDILANDS, A., VRENSEN, G.J.F.M. and GRAW, J. (1998) Three murine cataract mutants (Cat2) are defective in different $\gamma$-crystallin genes. Genomics 52: 152-158.

KMOCH, S., BRYNDA, J., ASFAW, B., BEZOUSKA, K., NOVÁK, P., REZÁCOVÁ, P., ONDROVÁ, L., FILIPEC, M., SEDLÁCEK, J. and ELLEDER, M. (2000) Link between a novel human $\gamma \mathrm{D}$-crystallin allele and a unique cataract phenotype explained by protein crystallography. Hum. Mol. Genet. 9, 1779-1786.

KOOPMAN, P. (1999) Sryand Sox9. mammalian testis-determining genes. Cell. Mol. Life Sci. 55: 839-856.
KRATOCHVILOVA, J. (1981) Dominant cataract mutations detected in offspring of gamma-irradiated male mice. J. Hered. 72: 302-307

KRATOCHVILOVA, J. and EHLING, U.H. (1979) Dominant cataract mutations induced by $\gamma$-irradiation of male mice. Mutat. Res. 63: 221-223.

KRATOCHVILOVA. J. and FAVOR, J. (1992) Allelism tests of 15 dominant cataract mutations in mice. Genet. Res. Camb. 59: 199-203.

LITT, M., CARRERO-VALENZUELA, R., LAMORTICELLA, D., SCHULTZ, D.W. MITCHELL, T.N., KRAMER, P. and MAUMENEE, I.H. (1997) Autosomal dominant cerulean cataract is associated with a chain termination mutation in the human $\beta$-crystallin gene CRYBB2. Hum. Mol. Genet. 6: 665-668.

LITT, M., KRAMER, P., LAMORTICELLA, D.M., MURPHEY, W., LOVRIEN, E.W. and WELEBER, R.G. (1998) Autosomal-dominant congenital cataract associated with a missense mutation in the human alpha-crystallin gene $C R Y A A$. Hum. Mol. Genet. 7: 471-474.

LÖSTER, J., IMMERVOLL, T., SCHMITT-JOHN, T. and GRAW, J. (1997) Cat3v' and Cat3 ${ }^{\text {vao }}$, cataract mutations on mouse chromosome 10: phenotypic characterization, linkage studies and analysis of candidate genes. Mol. Gen. Genet. 257: 97-102.

LYON, M.F., JAMIESON, R.V., PERVEEN, R., GLENISTER, P.H., GRIFFITHS, R BOYD, Y., GLIMCHER, L.H., FAVOR, J., MUNIER, F.L. and BLACK, G. (2003) A dominant mutation within the DNA-binding domain of the bZIP transcription factor Maf causes murine cataract and results in selective alteration in DNA binding. Hum. Mol. Genet. 12: 585-594.

LYON, M.F., JARVIS, S.E., SAYERS, I. and HOLMES, R.S. (1981) Lens opacity: a new gene for congenital cataract on chromosome 10 of the mouse. Genet. Res. Camb. 38: 337-341.

MACKAY, D.S., ANDLEY, U.P. and SHIELS, A. (2003) Cell death triggered by a novel mutation in the $\alpha A$-crystallin gene underlies autosomal dominant cataract linked to chromosome 21q. Eur. J. Hum. Genet. 11:784-793.

MACKAY, D.S., ANDLEY, U.P., SHIELS, A. (2004) A missense mutation in the $\gamma D$ crystalline gene (CRYGD) associated with autosomal dominant "coral-like" cataract linked to chromosome 2q. Mol. Vis. 10: 155-162.

MACKAY, D.S., BOSKOVSKA, O.B., KNOPF, H.L.S., LAMPI, K.J. and SHIELS, A. (2002) A nonsense mutation in $C R Y B B 1$ associated with autosomal dominan cataract linked to human chromosome 22q. Am. J. Hum. Genet. 71:1216-1221.

MACKAY, D., IONIDES, A., KIBAR, Z., ROULEAU, G., BERRY, V., MOORE, A., SHIELS, A. and BHATTACHARYA, S. (1999) Connexin46 mutations in autosomal dominant congenital cataract. Am. J. Hum. Genet. 64: 1357-1364.

MATSUO, T., OSUMI-YAMASHITA, N., NOJI, S., OHUCHI, H., KOYAMA, E., MYOKAI, F., MATSUO, N., TANIGUCHI, S., DOI, H., ISEKI, S., NINOMIYA, Y., FUJIWARA, M., WATANABE, T. and ETO, K. (1993) A mutation in the Pax-6 gene in rat small eye is associated with impaired migration of midbrain crest cells. Nat. Genet. 3: 229-304

MATSUSHIMA, Y., KAMOTO, T., IIDA, F., ABUJANG, P., HONDA, Y, and HIAI, H. (1996) Mapping of rupture of lens cataract (rlc) on mouse chromosome 14. Genomics 36: 553-554.

MCCARTY, C. (2003) The importance of epidemiology in the effort of reducing world blindness due to cataract. Ophthal. Res. 35 (S1): 264.

MÖRNER, C.T. (1893) Untersuchungen der Proteinsubstanzen in den lichtbrechenden Medien des Auges. Z. Physiol. Chem. 18: 61-106.

MORRISON, D., FITZPATRICK, D., HANSON, I., WILLIAMSON, K., VAN HEYNINGEN, V., FLECK, B., JONES, I., CHALMERS, J. and CAMPBELL, H. (2002) National study of microphthalmia, anophthalmia, and coloboma (MAC) in Scotland: investigation of genetic etiology. J. Med. Genet. 39: 16-22.

MUGGLETON-HARRIS, A.L., FESTING, M.F.W. and HALL, M. (1987) A gene location for the inheritance of the Cataract Fraser $\left(C a t^{F r}\right)$ mouse congenital cataract. Genet. Res. Camb. 49: 235-238.

NANDROT, E., SLINGSBY, C., BASAK, A., CHEDRIF-CHEFCHAOUNI, M. BENAZZOUZ, B., HAJAJI, Y., BOUTAYEB, S., GRIBOUVAL, O., ARBOGAST, L., BERRAHO, A., ABITBOL, M. and HILAL, L. (2003) Gamma-D crystallin gene (CRYGD) mutation causes autosomal dominant congenital cerulean cataracts. J. Med. Genet. 40: 262-267

NISHIGUCHI, S., WOOD, H., KONDOH, H., LOVELL-BADGE, R. and EPISKOPOU V. (1998) Sox1 directly regulates the $\gamma$-crystallin gene and is essential for lens development in mice. Genes Dev. 12: 776-781. 
NISHIMURA, D.Y., SEARBY, C.C., ALWARD, W.L., WALTON, D., CRAIG, J.E., MACKEY, D.A., KAWASE, K., KANIS, A.B., PATIL, S.R., STONE, E.M. and SHEFFIELD, V.C. (2001) A spectrum of FOXC1 mutations suggests gene dosage as a mechanism for developmental defects of the anterior chamber of the eye. Am. J. Hum. Genet. 68:364-372.

NISHIZAWA, M., KATAOKA, K., GOTO, N., FUJIWARA, K.T. and KAWAI, S. (1989) v-maf, a viral oncogene that encodes a "leucine zipper" motif. Proc. Natl. Acad. Sci. USA 86: 7711-7715.

NUNES, I., TOVMASIAN, L.T., SILVA, R.M., BURKE, R.E. and GOFF, S.P. (2003) Pit 3 is required for development of substantia nigra dopam inergic neurons. ProC. Natl. Acad. Sci. USA 100: 4245-4250.

ODA, S.I., WATANABE, K., FUJISAWA, H. and KAMEYAMA, Y. (1980) Impaired development of lens fibers in genetic microphthalmia, eye lens obsolescence, Elo, of the mouse. Exp. Eye Res. 31: 673-681.

OGINO, H. and YASUDA, K. (1998) Induction of lens diffedrentiation by activation of a bZIP transcription factor, L-Maf. Science 280: 115-118.

OKAMURA, T., MIYOSHI, I., TAKAHASHI, K., MOTOTANI, Y., ISHIGAKI, S., KON, Y. and KASAI, N. (2003) Bilateral congenital cataracts result from a gain-offunction mutation in the gene for aquaporin-0 in mice. Genomics 81: 361-368.

PAZNEKAS, W.A., BOYADJIEV, S.A., SHAPIRO, R.E., DANIELS, O., WOLLNIK, B., KEEGAN, C.E., INNIS, J.W., DINULOS, M.B., CHRISTIAN, C., HANNIBAL, M.C. and JABS, E.W. (2003) Connexin 43 (GJA1) mutations cause the pleiotropic phenotype of oculodentodigital dysplasia. Am. J. Hum. Genet. 72: 408-418.

PELLEGATA, N.S., DIEGUEZ-LUCENA, J.L., JOENSUU, T., LAU, S., MONTGOMERY, K.T., KRAHE, R., KIVELÄ, T., KUCHERLAPATI, R., FORSIUS, H. and DE LA CHAPELLE, A. (2000) Mutations in KERA, encoding keratocan, cause cornea plana. Nat. Genet. 25: 91-95

PETERSON, C.A. and PIATIGORSKY, J. (1986) Preferential conservation of the globular domains of the $\beta A 3 / A 1$-crystallin polypeptide of the chicken eye lens. Gene 45:139-147.

PRAS, E., FRYDMAN, M., LEVY-NISSENBAUM, E., BAKHAN, T., RAZ, J., ASSIA, E.I., GOLDMAN, B. and PRAS, E. (2000) A nonsense mutation (W9X) in $C R Y A A$ causes autosomal recessive cataract in an inbred Jewish Persian family. Invest. Ophthalmol. Vis. Sci. 41: 3511-3515.

PRAS, E., LEVY-NISSENBAUM, E., BAKHAN, T., LAHAT, H., ASSIA, E., GEFFENCARMI, N., FRYDMAN, M., GOLDMAN, B. and PRAS, E. (2002) A missense mutation in the LIM2 gene is associated with autosomal recessive presenile cataract in an inbred Iraqi Jewish family. Am. J. Human. Genet. 70: 1363-1367.

PROSSER, J. and VAN HEYNINGEN, V. (1998) PAX6 mutations reviewed. Hum. Mutat. 11: 93-108.

QI, Y., JIA, H., HUANG, S., LIN, H., GU, J., SU, H., ZHANG, T., GAO, Y., QU, L., LI, D. and $\mathrm{LI}, \mathrm{Y}$. (2004) A deletion mutation in the $\beta A 1 / A 3$ crystallin gene (CRYBA1/ $A 3$ is associated with autosomal dominant congenital nuclear cataract in a Chinese family. Hum. Genet. 114: 192-197.

REDDY, M.A., BATEMAN, O.A., CHAKAROVA, C., FERRIS, J., BERRY, V., LOMAS, E., SARRA, R., SMITH, M.A., MOORE, A.T., BHATTACHARYA, S.S. and SLINGSBY, C. (2004) Characterization of the G91del CRYBA1/3-crystallin protein: a cause of human inherited cataract. Hum. Mol. Genet. 13: 945-953.

REES, M.I., WATTS, P., FENTON, I., CLARKE, A., SNELL, R.G., OWEN, M.J. and GRAY, J. (2000) Further evidence of autosomal dominant congenital zonular pulverulent cataracts linked to $13 q 11$ ( CZP3) and a novel mutation in connexin 46 (GJA3). Hum. Genet. 106: 206-209.

REN, Z., LI, A., SHASTRY, B.S., PADMA, T., AYYAGARI, R., SCOTT, M.H., PARKS, M.M., KAISER-KUPFER, M.I. and HEJTMANCIK, J.F. (2000) A 5-base insertion in the $\gamma \mathrm{C}$-crystallin gene is associated with autosomal dominant variable zonular pulverulent cataract. Hum. Genet. 106: 531-537.

RIEGER, D.K., REICHENBERGER, E., MCLEAN, W., SIDOW, A. and OLSEN, B.R. (2001) A double-deletion mutation in the Pitx3 gene causes arrested lens deveopment in aphakia mice. Genomics 72: 61-72.

RING, B.Z., CORDES, S.P., OVERBEEK, P.A. and BARSH, G.S. (2000) Regulation of mouse lens fiber cell development and differentiation by the Maf gene. Development 127: 307-317.

SANDILANDS, A., HUTCHESON, A.M., LONG, H.A., PRESCOTT, A.R., VRENSEN, G., LÖSTER, J., KLOPP, N., LUTZ, R.B., GRAW, J., MASAKI, S., DOBSON, C.M., MACPHEE, C.E. and QUINLAN, R.A. (2002) Altered aggregation properties of mutant $\gamma$-crystallins cause inherited cataract. EMBO J. 21: 6005-6014.
SANDILANDS, A., PRESCOTT, A.R., WEGENER, A., ZOLTOSKI, R.K., HUTCHESON; A.M., MASAKI, S., KUSZAK, J.R. and QUINLAN, R.A. (2003) Knockout of the intermediate filament protein CP49 destabilises the lens fibre cytoskeleton and decreases lens optical quality, but does not induce cataract. Exp. Eye Res. 76: 385-391.

SANDILANDS, A., WANG, X., HUTCHESON, A.M., JAMES, J., PRESCOTT, A.R., WEGENER, A., PEKNY, M., Gong, X. and QUINLAN, R.A. (2004) Bfsp2mutation found in mouse 129 strains causes the loss of CP49 and induces vimentindependent changes in the lens fibre cell cytoskeleton. Exp. Eye Res. 78: 109-123.

SANTHIYA, S.T., ABD-ALLA, S.M., LÖSTER, J. and GRAW, J. (1995) Reduced levels of $\gamma$-crystallin transcripts during embryonic development of murine Catzrop mutant lenses. Graefe's Arch. Clin. Exp. Ophthalmol. 233: 795-800.

SANTHIYA, S.T., MANISASTRY, S.M., RAWLLEY, D., MALATHI, R., ANISHETTY, S., GOPINATH, P.M., VIJAYALAKSHMI, P., NAMPERUMALSAMY, P. and GRAW, J. (2004). Mutation analysis in Indian families suffering from congenital cataracts: identification of several SNPs and a new causative allele in the CRYBB2 gene. Invest. Ophthalmol. Vis. Sci. 45: 3577-3607.

SANTHIYA, S.T., MANOHAR, M.S., RAWLLEY, D., VIJAYALAKSHMI, P., NAMPERUMALSAMY, P., GOPINATH, P.M., LÖSTER, J. and GRAW, J. (2002) Novel mutations in the $\gamma$-crystallin genes cause autosomal dominant congenital cataracts. J. Med. Genet. 39: 352-358.

SEMINA, E.V., BROWNELL, I., MINTZ-HITTNER, H.A., MURRAY, J:C:, and JAMRICH M. (2001) Mutations in the human forkhead transcription factor FOXE3 associated with anterior segment ocular dysgenesis and cataracts. Hum. Mol. Genet.10:231236.

SEMINA, E.V., FERRELL, R.E., MINTZ-HITTNER, H.A., BITOUN, P., ALWARD, W.L.M., REITER, R.S., FUNKHAUSER, C., DAACK-HIRSCH, S. and MURRAY, J.C. (1998) A novel homeobox gene PITX3is mutated in families with autosomaldominant cataracts and ASMD. Nat. Genet. 19: 167-170.

SEMINA, E., MURRAY, J.C., REITER, R., HRSTKA, R.F. and GRAW, J. (2000) Deletion in the promoter region and altered expression of Pitx3 homeobox gene in aphakia mice. Hum. Mol. Genet. 9: 1575-1585.

SEMINA, E.V., REITER, R.S. and MURRAY, J.C. (1997) Isolation of a new homeobox gene belonging to the Pitx/Rieg family: expression during lens development and mapping to the aphakia region on mouse chromosome 19. Hum Mol Genet 6 : 2109-2116.

SHENTU, X., YAO, K., XU, W., ZHENG, S., HU, S. and GONG, X. (2004) Special fasciculiform cataract caused by a mutation in the $\gamma \mathrm{D}$-crystallin gene. Mol. Vis. 10: 233-239.

SHIELS, A. and BASSNETT, S. (1996) Mutations in the founder of the MIP gene family underlie cataract development in the mouse. Nat. Genet. 12: 212-215.

SHIELS, A. and GRIFFIN, C.S. (1993) Aberrant expression of the gene for lens major intrinsic protein in the CAT mouse. Curr. Eye Res. 12: 913-921.

SHIELS, A., MACKAY, D., IONIDES, A., BERRY, V., MOORE, A. and BHATTACHARYA, S. (1998) A missense mutation in the human connexin50gene (GJA8) underlies autosomal dominant "zonular pulverulent" cataract, on chromosome 1q. Am. J. Hum. Genet. 62: 526-532.

SHIMADA, N., AYA-MURATA, T., REZA, H.M. and YASUDA, K. (2003) Cooperative action between L-Maf and Sox2 on $\delta$-crystallingene expression during chick lens development. Mech. Dev. 120: 455-465.

SIDJANIN, D.J., PARKER-WILSON, D.M., NEUHÄUSER-KLAUS, A., PRETSCH, W., FAVOR, J., DEEN, P.M.T., OHTAKA-MARUYAMA, C., LU, Y., BRAGIN, A., SKACH, W.R., CHEPELINSKY, A.B., GRIMES, P.A. and STAMBOLIAN, D.E. (2001) A 76-bp deletion in the Mip gene causes autosomal dominant cataract in Hfimice. Genomics 74: 313-319.

SINHA, D., ESUMI, N., JAWORSKI, C., KOZAK, C.A., PIERCE, E. and WISTOW, G. (1998) Cloning and mapping of the mouse Crygs gene and non-lens expression of $\gamma$ S-crystallin. Mol. Vis. 4: 8.

SMIDT, M.P., Smits, S.M., BOUWMEESTER, H., HAMERS, F.P.T., VAN DER LINDEN, A.J.A., HELLEMONS, A.J.C.G.M., GRAW, J. and BURBACH, J.P.H (2004) Early developmental failure of substantia nigra dopamine neurons in mice lacking the homeodomain gene Pitx3. Development 131: 1145-1155.

SMITH, R.S., HAWES, N.L., CHANG, B., RODERICK, T.H., AKESON, E.C., HECKENLIVELY, J.R., GONG, X., WANG, X. and DAVISSON, M.T. (2000) Lop12, a mutation in mouse Crygd causing lens opacity similar to human Coppock cataract. Genomics 63: 314-320. 
SONG, C.W., OKUMOTO, M., MORI, N., KIM, J.S., HAN, S.S. and ESAKI. K. (1997) Mapping of new recessive cataract gene (/r2) in the mouse. Mamm. Genome8: 927-931.

STAMBOLIAN, D., FAVOR, J., SILVERS, W., AVNER, P., CHAPMAN, V. and ZHOU, E. (1994) Mapping of the X-linked cataract (Xcat) mutation, the gene implicated in the Nance Horan Syndrome, on the mouse $X$ chromosome. Genomics 22: 377-380.

STEELE, E.C.JR, KERSCHER, S., LYON, M.F., GLENISTER, PH., FAVOR, J., WANG, J. and CHURCH, R.L. (1997). Identification of a mutation in the MP19 gene, Lim2, in the cataractous mouse mutant To3. Mol. Vis. 3: 5.

STEELE, E.C.JR, LYON, M.F., FAVOR, J., GUILLOT, P.V., BOYD, Y. and CHURCH, R.L. (1998) A mutation in the connexin 50( $C \times 59$ gene is a candidate for the No2 mouse cataract. Curr. Eye Res. 17: 883-889.

STEPHAN, D.A., GILLANDERS, E., VANDERVEEN, D., FREAS-LUTZ, D., WISTOW, G., BAXEVANIS, A.D., ROBBINS, C.M., VANAUKEN, A., QUESENBERRY, M.I., BAILEY-WILSON, J., JUO, S.H., TRENT, J.M., SMITH, L. and BROWNSTEIN, M.J. (1999) Progressive juvenile-onset punctate cataracts caused by mutation in the $\gamma \mathrm{D}$-crystallin gene. Proc. Natl. Acad. Sci. USA 96: 1008-1012.

ST.ONGE, L., SOSA-PINEDA, B., CHOWDHURY, K., MANSOURI, A. and GRUSS P. (1997) Pax6 is required for differentiation of glucagon-producing $\alpha$-cells in mouse pancreas. Nature 387: 406-409.

TAKEHANA, M. (1990) Hereditary cataract of the Nakano mouse. Exp. Eye Res. 50: 671-676.

UGA, S., KADOR, P.F. and KUWABARA, T. (1980) Cytological study of Philly mouse cataract. Exp. Eye Res. 30: 79-92.

VAN HEYNINGEN, V. and WILLIAMSON, K.A. (2002) PAX6 in sensory development. Hum. Mol. Genet. 11: 1161-1167.

VANITA, SARHADI, V., REIS, A., JUNG, M., SINGH, D., SPERLING, K., SINGH, J.R. and BURGER, J. (2001) A unique form of autosomal dominant cataract explained by gene conversion between $\beta$-crystallin B2 and its pseudogene. J. Med. Genet. 38: 392-396.

VARNUM, D.S. (1983): Blind-sterile: a new mutation on chromosome 2 of the house mouse. J. Hered. 74: 206-207.

VARNUM, D.S. and FOX, S.C. (1981) Head blebs: a new mutation on chromosome 4 of the mouse. J. Hered. 72: 293.

VARNUM, D.S. and STEVENS, L.C. (1968) Aphakia, a new mutation in the mouse. J. Hered. 59: 147-150.

VICART, P., CARON, A., GUICHENEY, P., Li, Z., PRÉVOST, M.C., FAURE, A., CHATEAU, D., CHAPON, F., TOMÉ, F., DUPRET, J.M., PAULIN, D. and FARDEAU, M. (1998) A missense mutation in the $\alpha B$-crystallin chaperone gene causes a desmin-related myopathy. Nat. Genet. 20:92-95.
WADA, E., KOYAMA-ITO, H. and MATSUZAWA, A. (1991) Biochemical evidence for conversion to milder form of hereditary mouse cataract by different genetic background. Exp. Eye Res. 52: 501-506.

WALTHER, C. and GRUSS, P. (1991) Pax-6, a murine paired box gene, is expressed in the developing CNS. Development 113: 1435-1449.

WEST, J.D. and FISHER, G. (1986) Further experience of the mouse dominant cataract mutation test from an experiment with ethylnitrosourea. Mutat. Res. 164: 127-136.

WHITE, T.W., BRUZZONE, R., GOODENOUGH, D.A. and PAUL, D.L. (1992) Mouse Cx50, a functional member of the connexin family of gap junction proteins, is the lens fiber protein MP70. Mol. Biol. Cel/3: 711-720

WHITE, T.W., GOODENOUGH, D.A. and PAUL, D.L. (1998) Targeted ablation of connexin50 in mice results in microphthalmia and zonular pulverulent cataracts. J. Cell Biol. 143: 815-825.

WILLOUGHBY, C.E., ARAB, S., GANDHI, R., ZEINALI, S, ARAB, S., LUK, D., BILLINGSLEY, G., MUNIER, F.L., HÉON, E. (2003) A novel GJA8mutation in an Iranian family with progressive autosomal dominant congenital nuclear cataract. J. Med. Genet. 40: e124.

WISTOW, G.J. and PIATIGORSKY, J. (1988) Lens crystallins: the evolution and expression of proteins for a highly specialized tissue. Annu. Rev. Biochem. 57 479-504.

WISTOW, G., SINHA, D., LYON, M., KOZAK, C., PIERCE, E., ESUMI, N. and JAWORSKI, C. (1998) $\gamma$ s-Crystallin in lens, retina and Opj cataract. Invest. Ophthalmol. Vis. Sci. 39: S523.

XIA, Y., WELCH, C.L., WARDEN, C.H., LANGE, E., FUKAO, T., LUSIS, A.J. and GATTI, R.A. (1996) Assignment of the mouse ataxia-telangiectasiagene (Atm) to mouse chromosome 9. Mamm. Genome 7: 554-555.

YU, L.C., TWU, Y.C., CHOLU, M.L., REID, M.E., GRAY, A.R., MOULDS, J.M., CHANG, C.Y. and LIN, M. (2003) The molecular genetics of the human I locus and molecular background explain the partial association of the adult I phenotype with congenital cataracts. Blood 101: 2081-2088.

ZHOU, E., FAVOR, J., SILVERS, W. and STAMBOLIAN, D. (1995) Exclusion of three candidate genes, Grpr, $C \times n 33$, and Pdha1, for the X-linked cataract gene on the distal region of the mouse chromosome X. Mamm. Genome 6:357-359.

ZHOU, E., GRIMES, P., FAVOR, J., KOEBERLEIN, B., PRETSCH, W., NEUHÄUSER-KLAUS, A., SIDJANIN, D. and STAMBOLIAN, D. (1997) Genetic mapping of a mouse ocular malformation locus, $\mathrm{Tcm}$, to chromosome 4. Mamm. Genome 8: 178-181.

ZHOU, L., CHEN, T. and CHURCH, R.L. (2002) Temporal expression of three mouse lens fiber cell membrane protein genes during early development. Mol. Vis. 8: $143-148$

ZWAAN, J. and WILLIAMS, R.M. (1969) Cataracts and abnormal proliferation of the lens epithelium in mice carrying the Cat ${ }^{F r}$ gene. Exp. Eye Res. 8: 161-167. 